\title{
OPOWIEŚĆ O ZDOBYCIU KONSTANTYNOPOLA PRZEZ UCZESTNIKÓW CZWARTEJ WYPRAWY KRZYŻOWEJ (6712/1204) W ŚREDNIOWIECZNEJ RUSKIEJ TRADYCJI HISTORIOGRAFICZNEJ
}

\author{
AN ACCOUNT ABOUT THE SIEGE OF CONSTANTINOPLE BY PARTICIPANTS \\ OF THE FOURTH CRUSADE (6712/1204) IN THE MEDIEVAL RUSSIAN \\ HISTORIOGRAPHICAL TRADITION
}

\begin{abstract}
The Old-Russian account about the siege of Constantinople by participants of the Fourth Crusade in 1204 has survived in several East Slavic historiographical texts and represents primarily an independent literary work. Certainly, the earliest of these texts is the Novgorod First Chronicle. It is an older edition preserved only in one copy - the so-called "Synodal manuscript", which was written in the middle of the thirteenth century. At that time the story was written. Its author could have taken information about the events he described directly from eyewitnesses. His account of events is characterized by objectivity and credibility and constitutes a valuable resource for the study of the Fourth Crusade.
\end{abstract}

Keywords: Old Russian literature, Novgorod the Great, Novgorod First Chronicle, Constantinople, Fourth Crusade.

Staroruska opowieść o zdobyciu Konstantynopola przez uczestników czwartej wyprawy krzyżowej w 1204 r., najprawdopodobniej stanowiąca pierwotnie samodzielny utwór literacki, dotrwała do naszych dni w obrębie kilku wschodniosłowiańskich tekstów historiograficznych. Z pewnością najwcześniejszym z nich jest zabytek średniowiecznego kronikarstwa Nowogrodu Wielkiego, Latopis nowogrodzki pierwszy starszej redakcji, zachowany w jednym tylko odpisie - tzw. „rękopisie synodalnym”, ГИМ, Синод. собр., № 786 (Мещерский 1954, s. 122; Мещерский 1956, s. 171-172; Freydank 1968, s. 355; Заборов 1971, s. 89-90, 98; Творогов 1975, s. 148; Творогов 1987, s. 353; Patri 1988, s. 461, 463, 472; Гиппиус 1997, s. 52; Лучицкая 2006, s. 107, 113). Warto odnotować, że interesująca nas tu relacja, umiejscowiona pod datą roczną 6712/1204, na kartach 64-72,

\footnotetext{
* Katedra Filologii Słowiańskiej, Uniwersytet Łódzki, ul. Pomorska 171/173, 90-236 Łódź; Centrum Badań nad Historią i Kulturą Basenu Morza Śródziemnego i Europy Południowo-Wschodniej im. prof. Waldemara Cerana, Ceraneum, Uniwersytet Łódzki, ul. Matejki 32/38, sala 209, 90-237 Łódź; zbrzozowska@uni.lodz.pl.
} 
znajduje się w najstarszej części tego kodeksu, obejmującej opis wydarzeń z lat 1016-1234, powstałej - zdaniem znawców zagadnienia - w połowie XIII stulecia (Мещерский 1954, s. 122-123; Мещерский 1956, s. 172; Творогов 1987, s. 353; Гиппиус 1997, s. 3-72; Лучицкая 2006, s. 113).

Opowieść pojawia się też $\mathrm{w}$ nieomal niezmienionym kształcie $\mathrm{w}$ istniejących odpisach młodszego wariantu Latopisu nowogrodzkiego pierwszego: „komisyjnym” (ФИРИ РАН, собр. Археогр. ком., № 240, fol. 126-130) i ,akademickim” (БРАН, 17.8.36), datowanych na lata 40. XV w. (Мещерский 1954, s. 123; Мещерский 1956, s. 172; Творогов 1975, s. 148; Творогов 1987, s. 353; Patri 1988, s. 463; Гиппиус 1997, s. 3). Co więcej, została również włączona w obręb drugiej redakcji Latopisu helleńskiego i rzymskiego - obszernego utworu historiograficznego, którego autorzy podjęli próbę przedstawienia dziejów średniowiecznej Rusi na szerokim tle historii powszechnej, czerpiąc przy tym pełnymi garściami zarówno z zabytków rodzimego latopisarstwa, jak i źródeł proweniencji bizantyńskiej, znanych w staro-cerkiewno-słowiańskim przekładzie, tj. przede wszystkim kronik Jerzego Hamartolosa i Jana Malalasa (Лихачев 1948, s. 101; Patri 1988, s. 470-471; Творогов 1989, s. 18-19; Лучицкая 2006, s. 113). Opowieść o zdobyciu Konstantynopola przez łacinników nie została we wspomnianym latopisie zamieszczona pod rokiem 6712/1204, ale dość mechanicznie wpleciona w jego końcową część, zawierającą swego rodzaju rejestr cesarzy bizantyńskich i lat ich panowania, począwszy od Nikefora II Fokasa (963-969), a na Manuelu II Paleologu (1391-1425) skończywszy. Analizowany utwór wstawiono bezpośrednio po adnotacji na temat krótkich rządów Aleksego V Dukasa Murzuflosa, trwających od lutego do kwietnia 1204 r. (Лихачев 1948, s. 104; Клосс 1972, s. 375; Patri 1988, s. 471; Творогов 1989, s. 19). Biorąc pod uwagę fakt, iż Latopis helleński i rzymski nie zawiera informacji o zdobyciu Konstantynopola przez Turków Osmańskich, za terminus ante quem spisania jego drugiej, interesującej nas tu, redakcji uznaje się zazwyczaj rok 1453. Z połowy XV w. pochodzą też jej najstarsze zachowane odpisy, np. ГИМ, Чуд. собр., № 51/353 (opowieść znajduje się w nim na kartach 451-461). Niektórzy badacze sugerują jednak, iż protograf omawianego zwodu mógł powstać nawet w pierwszej połowie XIII w., na północy Rusi (Лихачев 1948, s. 101, 103; Мещерский 1954, s. 123; Мещерский 1956, s. 172, 185; Freydank 1968, s. 355-356; Клосс 1972, s. 370-379; Творогов 1975, s. 148; Творогов 1987, s. 353; Patri 1988, s. 471; Творогов 1989, s. 18).

Za trzecią grupę odpisów analizowanego utworu uważa się manuskrypty, zawierające teksty kilku latopisów północnoruskich z XV-XVI w., bazujących, zdaniem pewnych uczonych, na niezachowanej do naszych dni kompilacji historiograficznej z pierwszej połowy XV w. - w starszej literaturze przedmiotu znanej jako „Zwód z roku 1448” lub „Zwód nowogrodzko-sofijski” (Patri 1988, s. 467-468, 472; Бобров 2001, s. 129-143). I tak, lekko zmieniony wariant opowieści o zdobyciu Konstantynopola przez łacinników odnajdujemy, pod datą roczną 6712/1204, na kartach: Latopisu sofijskiego pierwszego - utworu nowogrodzkiego z pierwszej 
połowy XV w. (Мещерский 1954, s. 123; Мещерский 1956, s. 172-173; Freydank 1968, s. 355; Творогов 1975, s. 148; Творогов 1987, s. 353; Patri 1988, s. 468-469; Лучицкая 2006, s. 113-114), tzw. „wielkoksiążęcego” zwodu moskiewskiego z końca XV w. (Freydank 1968, s. 355; Patri 1988, s. 469), Latopisu wołogodzkopermskiego - kompilacji z pierwszej połowy XVI w. o charakterze ogólnoruskim (Творогов 1987, s. 353; Patri 1988, s. 469) oraz XVI-wiecznego Latopisu Zmartwychwstania (Мещерский 1954, s. 124; Творогов 1987, s. 353; Patri 1988, s. 469; Лучицкая 2006, s. 114). Tekst ten zamieszczono również w kilku odpisach Latopisu Nikonowskiego, monumentalnego dzieła historiografii moskiewskiej z XVI w. (Творогов 1987, s. 353; Лучицкая 2006, s. 114). Co ciekawe, omawianą opowieść włączono w obręb, bazującego na Latopisie Nikonowskim, bogato ilustrowanego zwodu (Лицевой свод), sporządzonego w jednym odpisie dla cara Iwana IV Groźnego w latach 60.-70. XVI wieku. Opis zdobycia Konstantynopola przez łacinników pojawia się na kartach piątego tomu tej kompilacji (РНБ, FIV.233) dwukrotnie: pod rokiem 6712/1204 (fol. 525-599') odnajdujemy analizowany tu utwór, przytoczony wiernie i bez poważniejszych skrótów, kilka zaś kart dalej - krótką informację na temat przebiegu czwartej krucjaty oraz jej konsekwencji dla cesarstwa bizantyńskiego (Подобедова 1981, s. 639-648; Patri 1988, s. 470).

Omawiana relacja posłużyła też z pewnością za wzór autorom zapisów o przebiegu wydarzeń w Konstantynopolu w latach 1203-1204, zamieszczonych w XVI-wiecznym Latopisie twerskim (Patri 1988, s. 470; Лучицкая 2006, s. 114-124) oraz Latopisie hustyńskim - południoworuskiej kompilacji kronikarskiej, datowanej obecnie na ok. 1670 r. (Заборов 1971, s. 105-106; Лучицкая 2006, s. 114-124). Warto odnotować, że istnieje polski przekład ostatniego z przywołanych tu zabytków (Suszko 2003, s. 175-176).

Manuskrypt Синод. собр., № 786 jest najstarszym zachowanym odpisem analizowanej opowieści, nie należy go jednak uznawać za jej protograf, ani też zakładać, iż została ona spisana jako integralna część Latopisu nowogrodzkiego pierwszego starszej redakcji. Z pewnością stanowiła pierwotnie samodzielny tekst literacki, włączony w obręb wspomnianego zwodu w trakcie prac nad jego najwcześniejszą częścią, obejmującą - jak była już o tym mowa wyżej - opis wydarzeń do roku 1234 (Мещерский 1954, s. 124; Мещерский 1956, s. 174; Freydank 1968, s. 356-357; Patri 1988, s. 461, 463; Лучицкая 2006, s. 113). Za tezą tą przemawia przede wszystkim specyfika lingwistyczna zabytku. Język opowieści znacznie odbiega od języka pozostałych zapisów kronikarskich w początkowej partii Latopisu nowogrodzkiego pierwszego, charakteryzując się większą od nich archaicznością: w narracji na temat wypadków konstantynopolitańskich, umieszczonej pod rokiem 6712/1204, odnajdziemy chociażby konstrukcje składniowe, charakterystyczne dla piśmiennictwa staro-cerkiewno-słowiańskiego, jak np. dativus

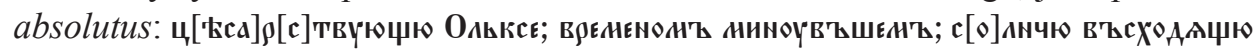


(Мещерский 1956, s. 184). Co więcej, w narracji dominuje południowosłowiańska forma rzeczownika oznaczającego gród lub miasto, występująca też w języku scs.: г९адт - została tu użyta aż 39 razy. Jej wschodniosłowiański (ruski) odpowiednik $(\Gamma \bullet \rho \mathcal{A}, \mathbf{z})$, niezwykle frekwentywny $\mathrm{w}$ innych zapisach Latopisu nowogrodzkiego pierwszego, w analizowanym utworze pojawia się natomiast tylko dwa razy. Ciekawych danych dostarcza też analiza paleograficzna rękopisu „synodalnego" - relacja została wpisana na karty kodeksu przez tego samego skrybę, co otaczające ją zapisy, niemniej jednak postarano się o graficzne podkreślenie jej odrębności, poprzedzając ją wyjątkowo sporym i ozdobnym inicjałem (R - fol. 64).

Włączenie interesującego nas tu tekstu w obręb najwcześniejszej części Latopisu nowogrodzkiego pierwszego starszej redakcji pozwala natomiast skonstatować, iż omawiana opowieść musiała powstać najpóźniej w połowie XIII w. (Клосc i Лурье 1976, s. 80-81; Гимон і Гиппиус 1999, s. 18-47). Jej autor mógł więc czerpać informacje o opisywanych przez siebie wydarzeniach bezpośrednio od ich naocznych świadków. Wielu badaczy posuwa się w swych przypuszczeniach jeszcze o krok dalej i sugeruje, że Rusin ten osobiście przebywał w Konstantynopolu w latach 1203-1204 i spisał swoją relację na podstawie własnych wspomnień (Meщерский 1954, s. 120, 127; Мещерский 1956, s. 170, 177, 185; Заборов 1971, s. 90, 98; Gordon 1973, s. 297, 304-305; Творогов 1987, s. 353; Madden 1995, s. 729; Бицилли 2006, s. 604; Лучицкая 2006, s. 114, 117). Za tą ostatnią hipotezą przemawia szereg argumentów. Przede wszystkim warto zwrócić uwagę na fakt, iż twórca naszej opowieści zdaje się osobą dość dobrze zaznajomioną z topografią Konstantynopola. W toku narracji wymienia wiele obiektów bizantyńskiej stolicy, próbując podać ich oryginalne, greckie nazwy (Мещерский 1954, s. 128; Мещерский 1956, s. 179, 182; Лучицкая 2006, s. 116). Terminy te (Вєр-

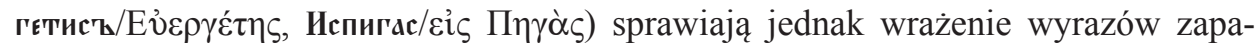
miętanych i zapisanych ze słuchu, podobnie jak miało to miejsce w większości itinerariów, stworzonych przez podróżników ruskich, zwiedzających metropolię nad Bosforem w XIII-XV w. (Мещерский 1954, s. 128; Мещерский 1956, s. 179, 182; Majeska 1984, s. 289, 337, 348-349; Patri 1988, s. 491; Лучицкая 2006, s. 116). Z tego i kilku innych powodów w starszej literaturze przedmiotu wysuwano niekiedy przypuszczenie, iż autorem omawianego tu zabytku był nie kto inny niż Dobrynia Jadrejkowicz, późniejszy arcybiskup nowogrodzki Antoni, który przebywał w Konstantynopolu w latach 1200-1204 i pozostawił po sobie jego obfitujący w szczegóły opis. Gruntowna analiza porównawcza języka i stylu itinerarium Dobryni oraz omawianego tu utworu wykluczyła jednak taką możliwość (Мещepский 1954, s. 122; Мещерский 1956, s. 171; Patri 1988, s. 465; Лучицкая 2006, s. 118).

Nie ulega natomiast wątpliwości, iż autor naszej opowieści, z pochodzenia Rusin, a być może nawet Nowogrodzianin, był osobą dość dobrze obeznaną z tajnikami żeglugi, techniką prowadzenia walk na morzu oraz zdobywania twierdz z wykorzystaniem okrętów. Problematyka ta zdaje się interesować go o wiele bardziej 
niż piękno konstantynopolitańskich kościołów czy wspaniałość zgromadzonych w nich relikwii, skarbów i dzieł sztuki. Pod tym względem charakter jego przekazu przypomina więc raczej relację Stefana z Nowogrodu, przebywającego nad Bosforem w 1348/1349 r. niż wspomnianego Dobryni-Antoniego (Brzozowska 2016, s. 227-260). I tak, na kartach opowieści odnaleźć możemy szczegółowy opis techniki walki obu stron konfliktu. Czytamy m.in. o ogniu greckim stosowanym przez Bizantyńczyków i o machinach oblężniczych, zbudowanych przez krzyżowców. Relatywnie sporo miejsca poświęca też nasz autor specyfice okrętów, którymi rozporządzali łacinnicy. Sumiennie notuje straty, poniesione przez oblegających $\mathrm{w}$ trakcie trwania walk oraz rozmiary zniszczeń w mieście, spowodowanych wywołanymi przez nich pożarami. Jedynie w końcowej partii utworu uwaga narratora zdaje się koncentrować przede wszystkim na świątyniach Konstantynopola. Anonimowy Rusin kreśli w niej sugestywny, a zarazem dość wyważony i obiektywny - w porównaniu z relacją Niketasa Choniatesa oraz przekazem autorów zachodnich (Roberta de Clariego i Geoffroya de Villehardouina) - obraz wandalizmu i grabieży, których dopuścili się uczestnicy czwartej wyprawy krzyżowej po wkroczeniu do bizantyńskiej stolicy (de Clari 1997; de Villehardouin 2003; Meщерский 1954, s. 128; Мещерский 1956, s. 179; Заборов 1971, s. 99-101; Лучицкая 2006, s. 116).

Nie wszystko mógł nasz podróżnik ujrzeć na własne oczy. Czytając jego tekst, można jednak odnieść wrażenie, że opisując te wydarzenia i miejsca, których nie znał z autopsji, posiłkował się raczej przekazem ustnym niż spisanymi post factum relacjami (Freydank 1968, s. 348; Бицилли 2006, s. 604; Лучицкая 2006, s. 115). Najprawdopodobniej głównym źródłem informacji były więc dla niego opowiadania innych naocznych świadków. Świadczy o tym chociażby forma, w jakiej podaje on imiona i tytuły, noszone przez przywódców krucjaty. Podobnie jak miało to miejsce w przypadku greckich nazw miejscowych, autor przytacza personalia osób, dowodzących zachodnioeuropejskim rycerstwem, w postaci zniekształconej - nierzadko nie rozumiejąc cytowanych przez siebie danych, np. nie odróżniając imienia od tytułu. I tak, Маюкосъ $\ddot{\mathbf{w}}$ Рина to właściwie marchio z Rzymu,

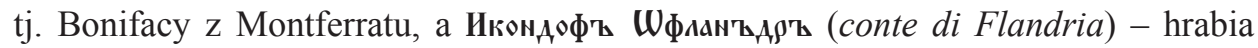
Flandrii Baldwin. Wiele również wskazuje na to, że nasz Rusin czerpał wiadomości na temat interesujących go wydarzeń i osób bezpośrednio z obozu krzyżowców, a konkretniej - z jego niemieckojęzycznej części. W jego przekazie odnaleźć można kilka elementów wspierających tę tezę. I tak, pisząc o Wenecji, używa on jej niemieckiej nazwy (Вєнєдик'ъ). Odwołuje się również do legendy o Dydryku z Bernu (tj. Werony), pojawiającej się w fabule wielu średniowiecznych eposów niemieckich, zwłaszcza zaś powstałej mniej więcej w tym samym okresie Pieśni o Nibelungach (Мещерский 1954, s. 131; Мещерский 1956, s. 182; Freydank 1968, s. 348; Заборов 1971, s. 104; Gordon 1973, s. 303-304; Bednarek 2001, s. 167, 172, 185-188; Бицилли 2006, s. 605-606; Лучицкая 2006, s. 120-121). 
Przytoczone wyżej fakty, biorąc pod uwagę, iż w XIII-XIV w. Nowogród Wielki utrzymywał dość ożywione kontakty z Niemcami w ramach Hanzy (Хорошкевич 1963, s. 31-34, 210; Gordon 1973, s. 304; Казакова 1975, s. 3; Dollinger 1997, s. 37, 59, 78), trudno byłoby uznać za jednoznaczny dowód bezpośredniej styczności autora opowieści z wywodzącymi się z tego kręgu kulturowego łacinnikami, gdyby nie jeszcze jeden element, tj. całkowicie zaskakujące poglądy naszego Nowogrodzianina na temat genezy czwartej wyprawy krzyżowej. Przyczyn dramatycznych wypadków z lat 1203-1204 i upadku bizantyńskiej stolicy twórca omawianej narracji dopatruje się bowiem przede wszystkim w waśniach w cesarskim rodzie Angelosów (Мещерский 1954, s. 132; Мещерский 1956, s. 183; Freydank 1968, s. 351-352; Лучицкая 2006, s. 122). Inicjatorem wyprawy zachodnioeuropejskiego rycerstwa na Konstantynopol jest, co prawda, król Niemiec Filip Szwabski (1198-1208), jego poczynania umotywowane są jednak przede wszystkim chęcią okazania pomocy bratu żony, młodemu Aleksemu [IV] Angelosowi, synowi cesarza Izaaka II (1185-1195), zdetronizowanego i oślepionego przez swego brata, Aleksego III (1195-1203). Co więcej, władca niemiecki zdaje się tu działać w ścisłym porozumieniu z papieżem Innocentym III (1198-1216), który w rzeczywistości - jako stronnik jego politycznego rywala, Ottona IV Welfa (króla Niemiec w latach 1198-1218, cesarza - 1209-1218) - pozostawał we wrogich relacjach z dworem Hohenstaufów. Autor staroruskiej opowieści podkreśla też, że Filip i Innocenty, wysyłając oddziały zbrojnych pod Konstantynopol, nakazali im osadzić Aleksego IV na tronie bazyleusów, nie wyrządzając najmniejszej bodaj szkody chrześcijańskim mieszkańcom cesarstwa. Winę za zdobycie i złupienie stolicy nad Bosforem ponoszą więc, zdaniem Nowogrodzianina, sami uczestnicy wyprawy, którzy ogarnięci żądzą zysku, świadomie zlekceważyli zakaz króla Filipa. Starając się zdjąć odpowiedzialność z władcy niemieckiego, twórca staroruski zwraca też uwagę w końcowej partii swych rozważań na inną wpływową postać z obozu krzyżowców, tj. dożę weneckiego Henryka Dandolo (1192-1205) (Freydank 1968, s. 346-349; Заборов 1971, s. 103-105; Gordon 1973, s. 298-301; Бицилли 2006, s. 604-608; Лучицкая 2006, s. 118-121). To on miał podsunąć zachodniemu rycerstwu pomysł zdobycia Konstantynopola, powodowany względami osobistymi - chęcią zemszczenia się na Bizantyńczykach za krzywdę, której rzekomo doznał od cesarza Manuela I Komnena (1143-1180). Sposób, w jaki autor opowieści ukazuje polityczne tło czwartej wyprawy krzyżowej, pozwala zatem przypuszczać, iż jego informatorem w obozie łacinników był niemieckojęzyczny stronnik Filipa Szwabskiego (Freydank 1968, s. 349; Gordon 1973, s. 298, 304; Лучицкая 2006, s. 115).

W tym miejscu warto dodać, iż w Latopisie helleńskim i rzymskim młodszej redakcji oraz zabytkach historiografii północnoruskiej z XV-XVI w. (Latopisie sofijskim pierwszym, ,wielkoksiążęcym” zwodzie moskiewskim, Latopisie wołogodzko-permskim, Latopisie Zmartwychwstania, niektórych odpisach Latopisu Nikonow- 
skiego oraz zwodzie ilustrowanym), bezpośrednio po tekście opowieści o zdobyciu Konstantynopola, umieszczono dwie krótkie narracje na temat sławnych przedmiotów kultu, znajdujących się w bizantyńskiej stolicy: czyniącej cuda ikony Bogurodzicy Hodegetrii, której autorstwo przypisywano św. Łukaszowi oraz relikwii szaty Matki Bożej, zdeponowanej w kościele w Blachernach (Мещерский 1954, s. 123; Мещерский 1956, s. 173; Freydank 1968, s. 355; Клосс 1972, s. 375, 379; Творогов 1975, s. 149-151; Patri 1988, s. 472; Лучицкая 2006, s. 119). Со ciekawe, utwory te nie pojawiają się na kartach Latopisu nowogrodzkiego pierwszego obu redakcji. Podobne do nich zapisy odnajdujemy natomiast w Latopisie nowogrodzkim czwartym pod datą roczną 6903/1395 (Бобров і Клосс 2000, s. 376-378). Część badaczy skłonna jest przypuszczać, iż powstały one na podstawie itinerarium diakona Aleksandra, zwiedzającego metropolię nad Bosforem pod koniec XIV stulecia (Клосс 1972, s. 379; Творогов 1975, s. 149-151; Majeska 1984, s. 156-165).

Istnieje wiele edycji omawianego utworu w obrębie Latopisu nowogrodzkiego pierwszego starszej redakcji według tzw. „rękopisu synodalnego": Летописеи новгородский, начинаюшийся от 6525/1017 2. и кончающийся 6860/1352 2., Москва 1781 [=Москва 1819], s. 79-89; Новгородскія лгтописи, Полное собрание русских летописей III, Санкт-Петербург 1841 [=Москва 2000], s. 26-29; Новгородская летопись по Синодальному харатейному списку, red. П.И. Савваитов, Санкт-Петербург 1888, s. 180-188; Новгородская первая летопись старшего и младшего изводов, red. А.Н. Насонов, М.Н. Тихомиров, Москва-Ленинград 1950, s. 46-46. Wykonano również dwa całościowe wydania fototypiczne manuskryptu ГИМ, Синод. собр., № 786: Новгородская летопись по Синодальному харатейному списку, Санкт-Петербург 1875; Новгородская харатейная летопись, red. М.Н. Тихомиров, Москва 1964. Ostatnia z wymienionych publikacji, zawierająca zdjęcia dość dobrej jakości, jest podstawą kolejnych autorskich edycji zabytku, publikowanych paralelnie z tłumaczeniem na nowożytne języki europejskie przez badaczy zachodnich. Na samodzielnym odczycie rękopisu ГИМ, Синод. собр., № 786, opierając się na fotokopiach M.N. Tichomirowa, bazuje również niniejsza edycja i przekład.

Opowieść o zdobyciu Konstantynopola przez uczestników czwartej wyprawy krzyżowej była wielokrotnie tłumaczona. Jako integralna część Latopisu nowogrodzkiego pierwszego została uwzględniona we wszystkich całościowych przekładach tego źródła, bazujących na rękopisie ГИМ, Синод. собр., № 786: wykonanym już na początku XX w. przez Roberta Michella i Nevilla Forbesa thumaczeniu na język angielski (The Chronicle of Novgorod 1016-1471, tłum. R. Michell, N. Forbes, red. C. Raymond Beazley, A.A. Shakhmatov, London 1914 [reedycja: New York 1970], s. 43-48), przekładzie niemieckim Joachima Dietze (Die Erste Novgoroder Chronik nach ihrer ältesten Redaction (Synodalhandschrift) 1016-1330/1352, tłum. J. Dietze, Leipzig 1971, s. 79-83) oraz wydaniu duńskim (Den 
Forste Novgorod-Kronike: Aldste Affattelse, tłum. K. Rahbek-Schmidt, Kobenhavn 1964). Znaczenie omawianego utworu dla badań nad przebiegiem wydarzeń w latach 1203-1204 warunkowało jednak konieczność powstania kolejnych, odrębnych naukowych edycji zabytku oraz jego tłumaczeń na języki nowożytne, przede wszystkim zachodnioeuropejskie. Przez dłuższy czas mediewiści zachodni, niemający możliwości zapoznania się ze staroruskim oryginałem narracji, opierali swoje badania na jej łacińskim przekładzie, opublikowanym w 1873 r. przez Karla Hopfa (Chroniques gréco-romanes inédites ou peu connues, red. Ch. Kopf, Berlin 1873, s. 93-98). W 1950 r. został on przetłumaczony na język hiszpański przez Sarę Isabel de Mundo (De Mundo 1950, s. 135-141). W drugiej połowie XX w. zaczęły się natomiast pojawiać kolejne przekłady, bazujące bezpośrednio na tekście rękopisu „synodalnego" Latopisu nowogrodzkiego pierwszego: w 1968 r. na łamach czasopisma „Byzantinoslavica” ukazało się tłumaczenie opowieści o zdobyciu Konstantynopola na język niemiecki, autorstwa Dietricha Freydanka, powstałe na podstawie edycji A.N. Nasonowa i M.N. Tichomirowa z 1950 r. (Freydank 1968, s. 339-344). Rok później O.W. Tworogow opublikował swój pierwszy przekład zabytku na współczesny język rosyjski (w tomie: Изборник. Сборник произведений литературы Древней Руси, Москва 1969, s. 280-289). Praca ta była kilkakrotnie wznawiana, z uwzględnieniem poprawek i późniejszych zmian, naniesionych przez jej autora (w zbiorach: Памятники Литературы Древней Руси. ХІІІ век, Москва 1981, s. 106-113; Библиотека литературы Древней Руси; red. Д.С. Лихачев, Л.А. Дмитриев, А.А. Алексеев, Н.В. Понырко, vol. 5, ХІІІ век, Санкт-Петербург 1997). W 1973 r. na łamach periodyku „Byzantion” wydano tłumaczenie angielskie, przygotowane przez Jareda Gordona (Gordon 1973, s. 306311), a w 1988 r. w tym samym czasopiśmie - przekład francuski autorstwa Sylvaina Patriego (Patri 1988, s. 476-501). W ostatnim czasie pojawiło się też tłumaczenie omawianego utworu na język bułgarski (Ракова 2007, s. 165-176). Istnieje również fragmentaryczny przekład polski, opublikowany przez Aleksandra Naumowa i Jana Stradomskiego (Naumow i Stradomski 2005, s. 241-242).

\section{TEKST ŹRÓDŁA W ORYGINALE STARORUSKIM}

Tekst według rękopisu „synodalnego" Latopisu nowogrodzkiego pierwszego starszej redakcji (ГИМ, Синод. собр., № 786, fol. 64-72). Wewnętrzny podział źródła został wprowadzony przez autorkę niniejszej edycji.

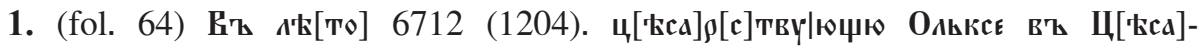

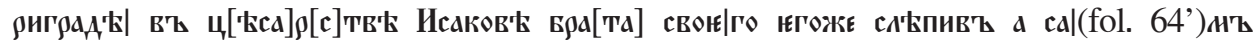

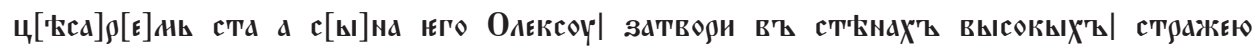

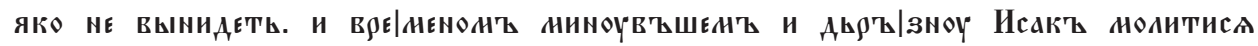

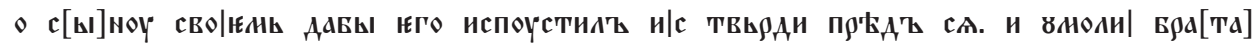




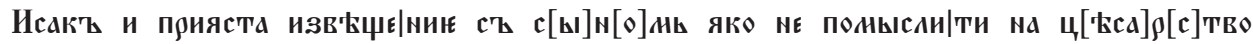

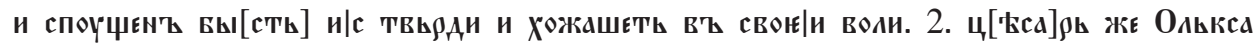
не ПЕЧА|ШеС

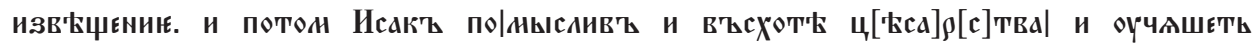

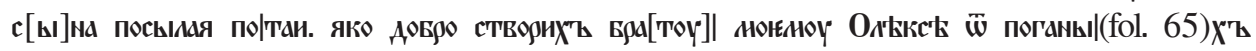

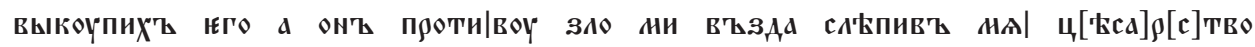

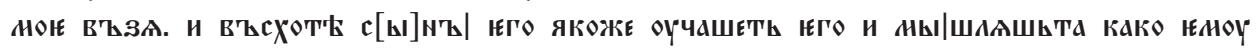

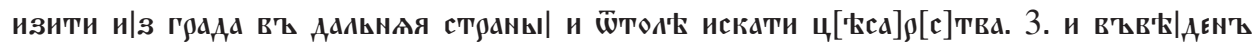

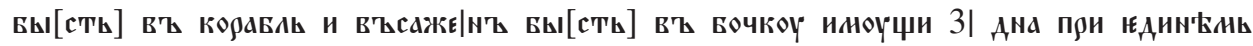

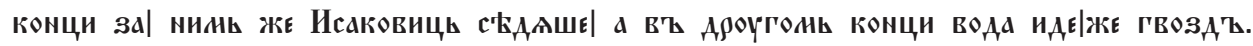

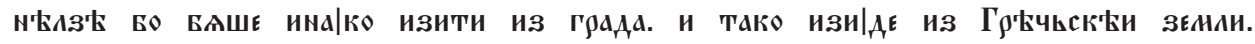

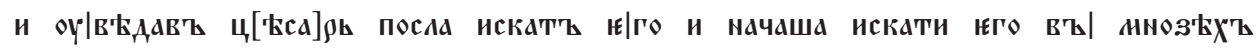

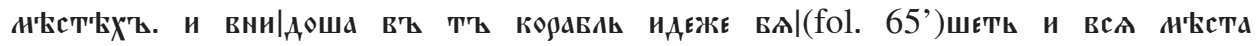

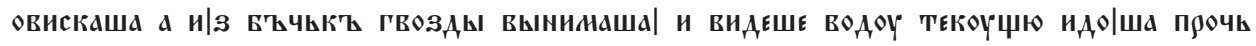

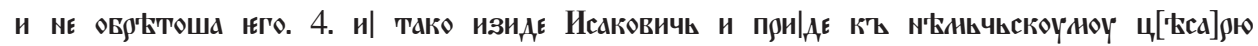

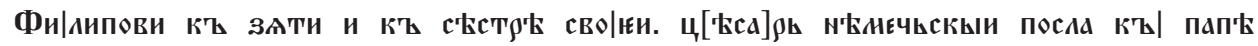

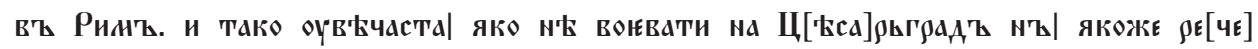

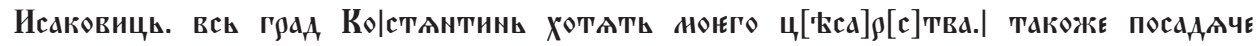

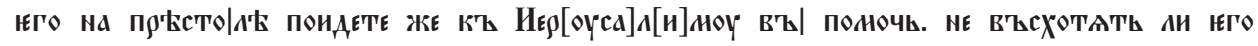

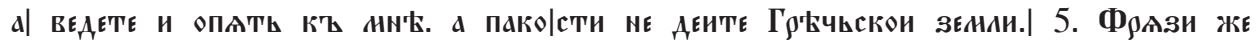

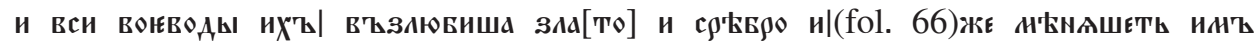

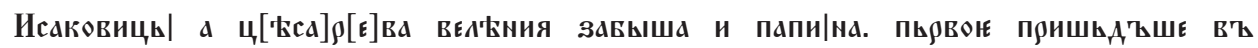

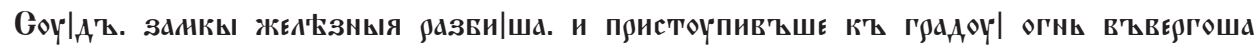

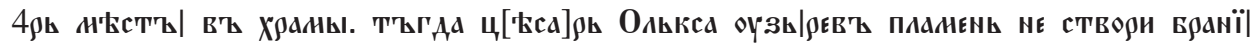

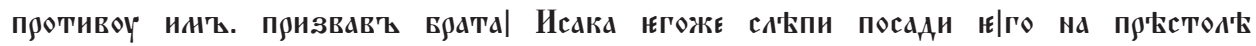

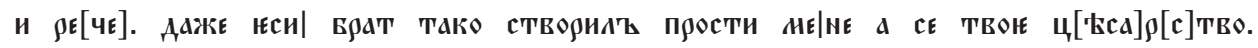

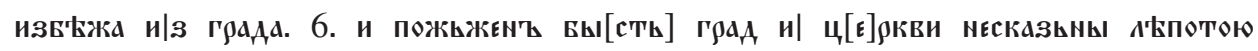

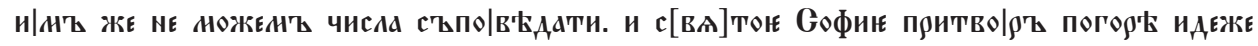

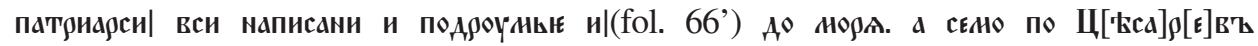

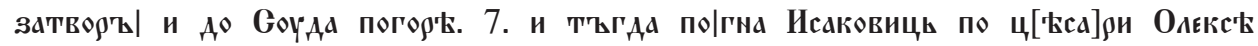

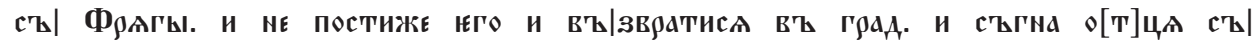

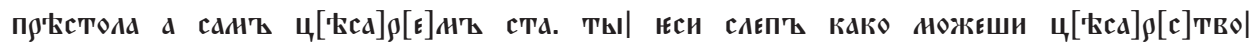

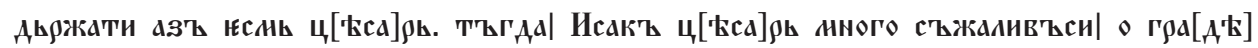

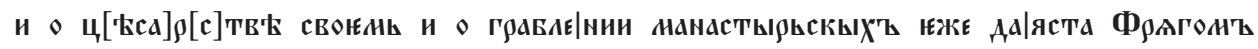
зАа[ТА] и с

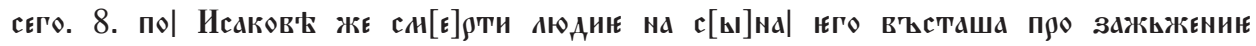

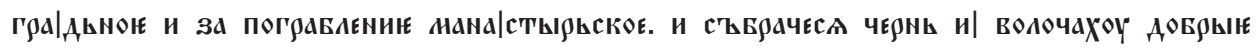

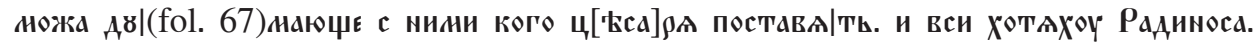

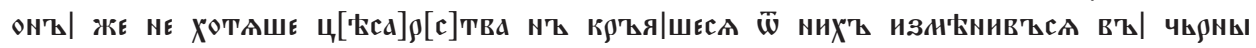

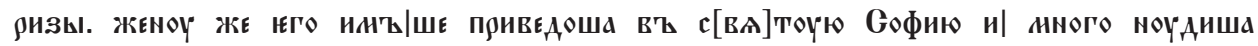

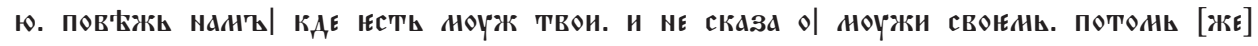

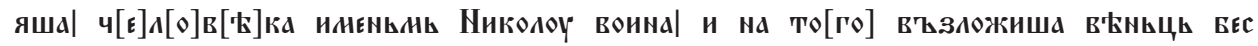




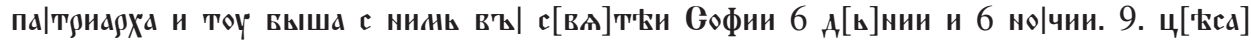

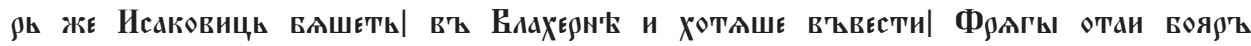

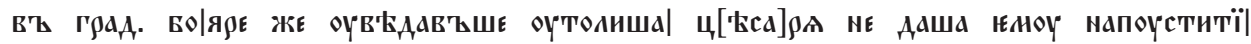

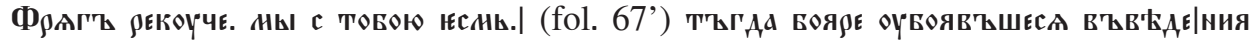

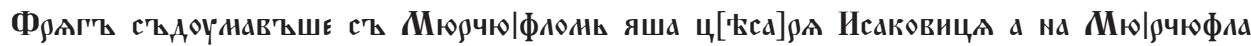

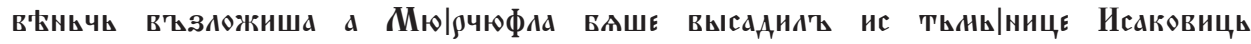

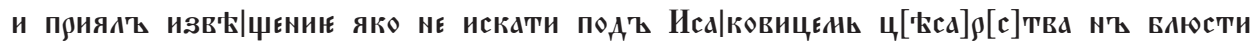

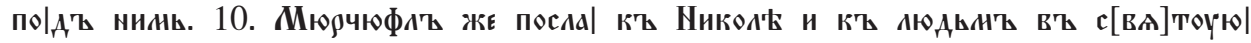

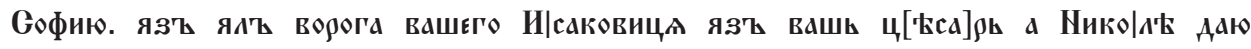

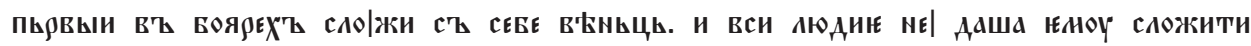

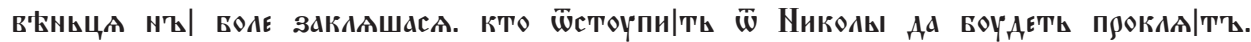

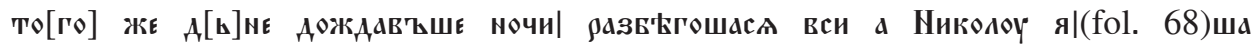

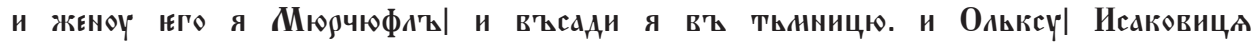

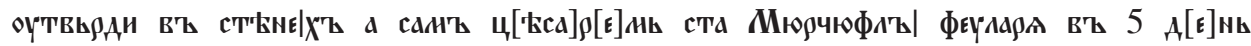

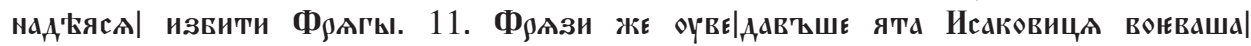

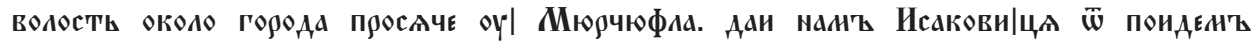

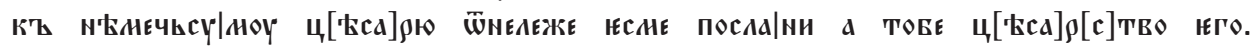

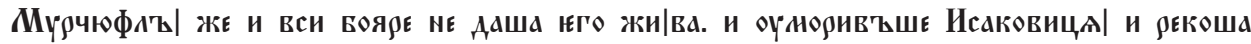

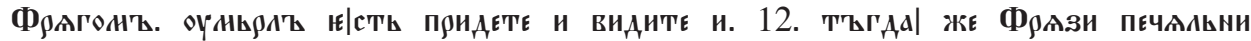

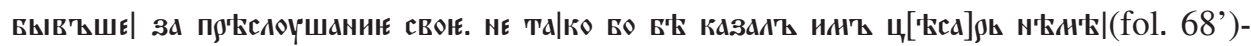

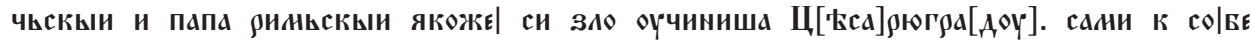

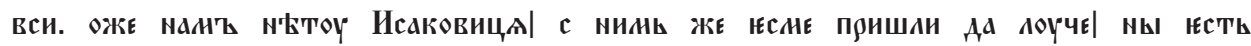

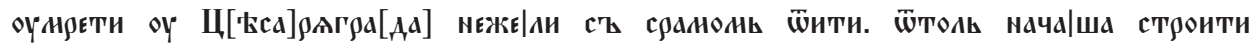

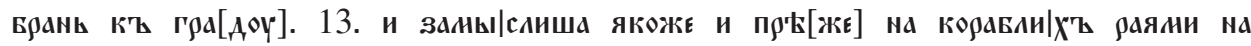

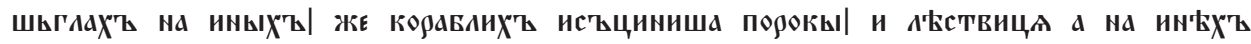

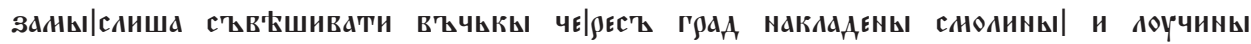

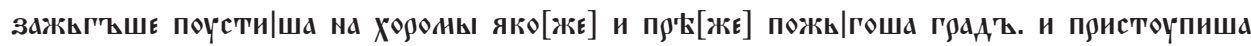

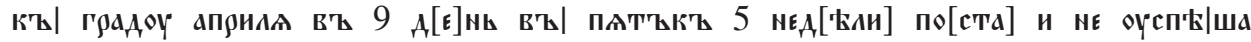

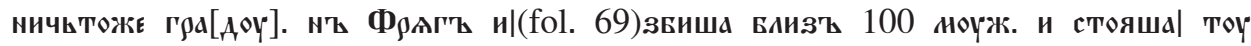

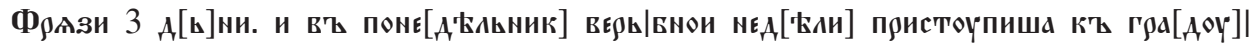

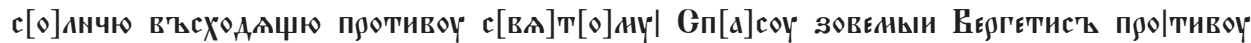

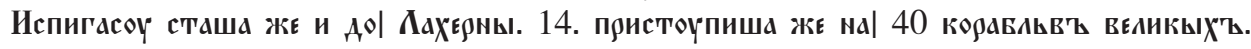

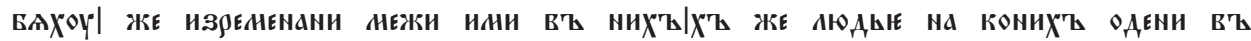

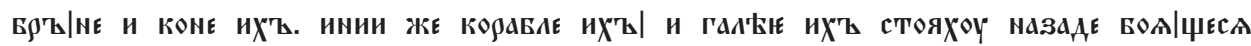

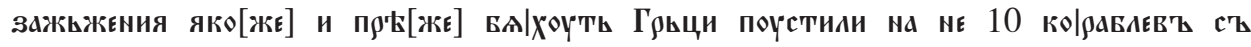

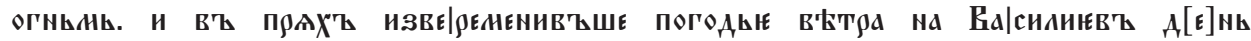

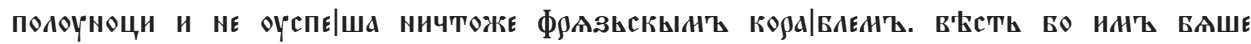

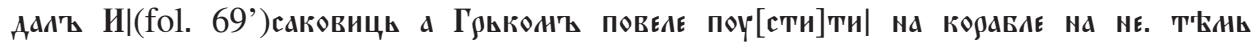

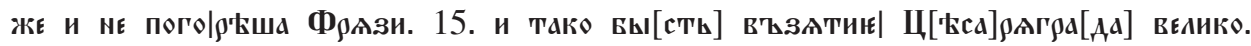

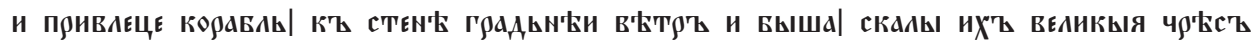

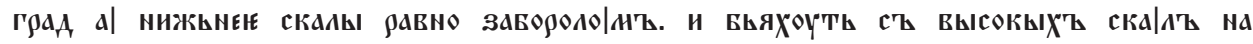

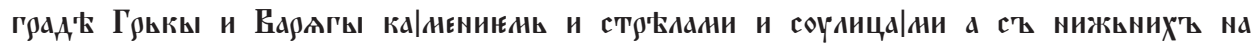




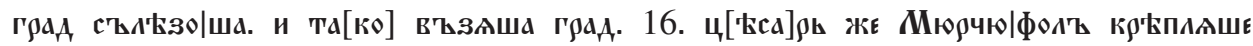

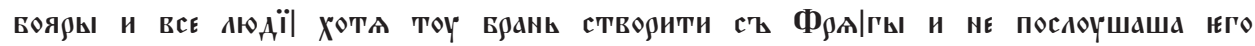

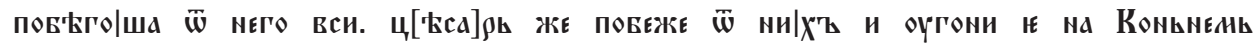

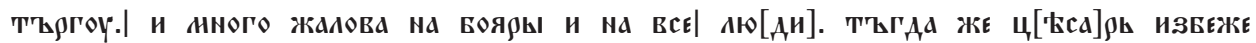
изъ|(fol. 70) Г९а[Аа] и пат

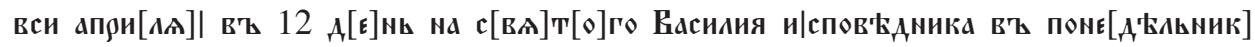

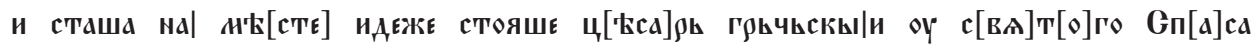

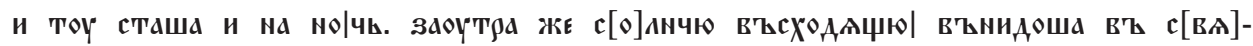

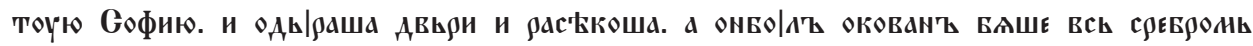

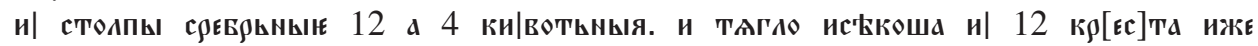

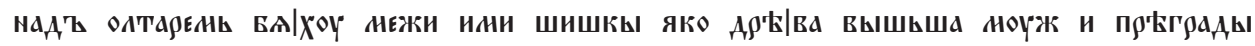

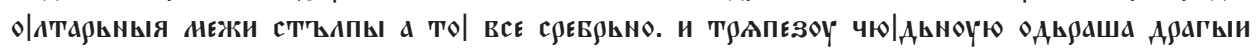

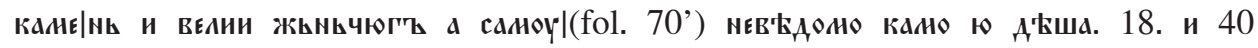

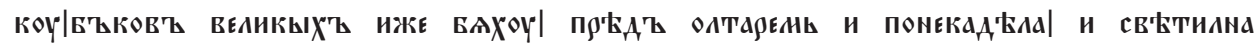

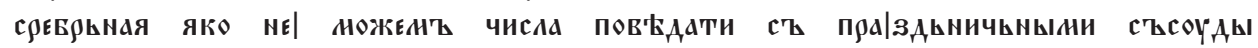

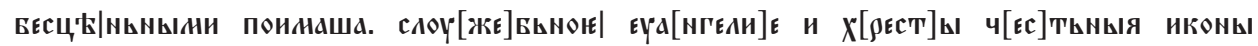

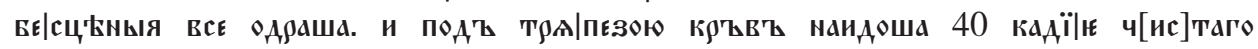

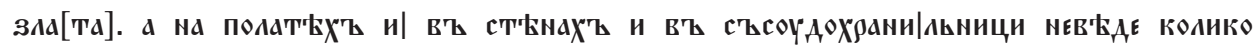

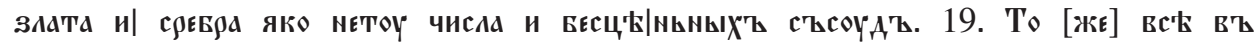

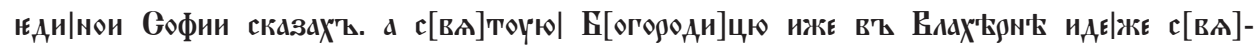

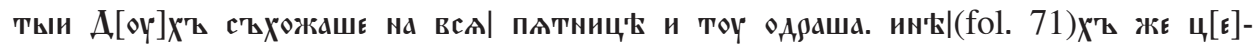

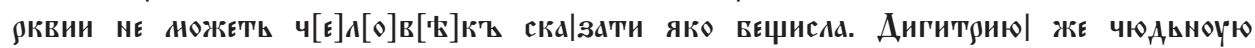

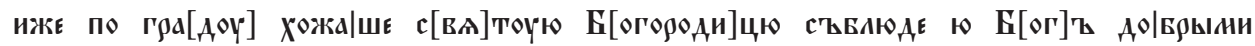

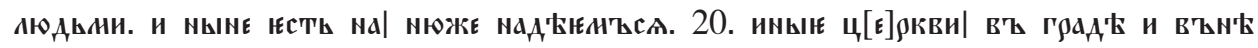

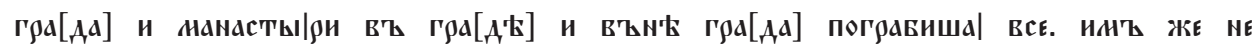

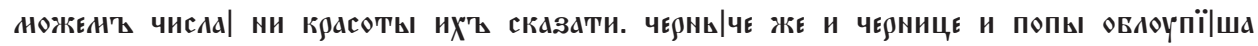

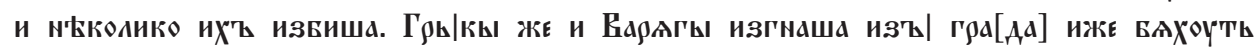

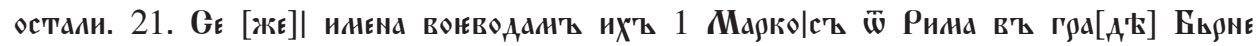

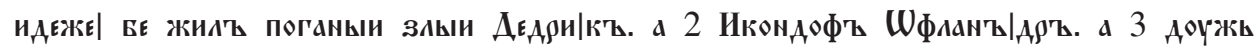

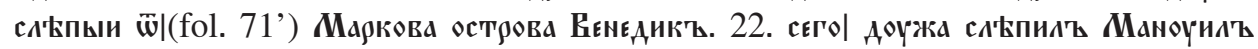
ц[Ћса]

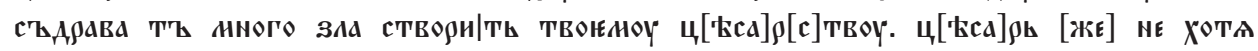

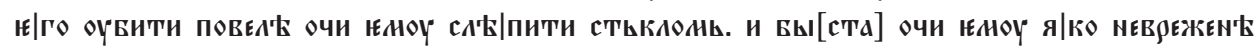

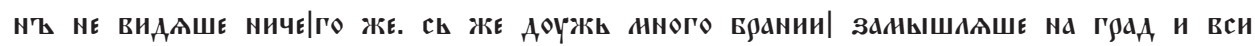

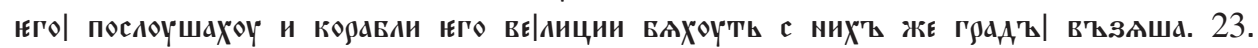

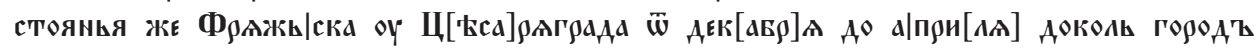

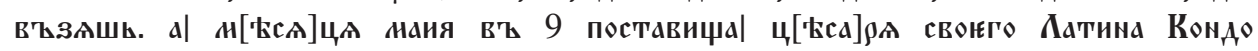

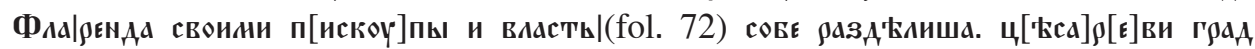

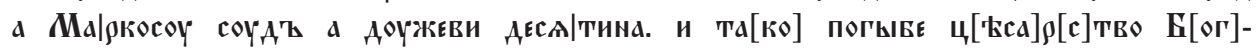

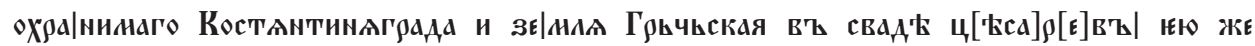
овладантть Ф९ази. 
1. Roku 6712 (1204). Panował wówczas w Carogrodzie Aleksy ${ }^{1}$, nad cesarstwem Izaaka ${ }^{2}$, brata swojego, którego oślepiwszy sam został cesarzem, a syna jego Aleksego $0^{3}$ uwięził w twierdzy wysokiej, pod strażą, aby nie mógł z niej uciec. Kiedy upłynęło trochę czasu, ośmielił się Izaak błagać za swoim synem, aby [cesarz] wypuścił go z więzienia. I uprosił brata Izaak i obaj z synem złożyli przysięgę, że nie będą spiskować przeciwko cesarstwu. I został [Aleksy] uwolniony z twierdzy i przebywał na wolności. 2. Cesarz zaś Aleksy nie obawiał się go, wierząc bratu Izaakowi i jego synowi, którzy wszak złożyli przysięgę. Później jednak Izaak, namyśliwszy się, zapragnął władzy cesarskiej i pouczał syna, śląc mu potajemnie [listy]: „wyrządziłem dobro mojemu bratu Aleksemu, wykupiłem go z rąk pogan, a on - przeciwnie - złem mi odpłacił, oślepiwszy mnie, zagarnął moje cesarstwo"4. I zapragnął jego syn tego, na co był nastawiany i zamyślali obaj, w jaki sposób [mógłby Aleksy] wyjechać z miasta w dalekie strony i stamtąd upomnieć się o tron. 3. I zaprowadzony został na statek i wsadzony do beczki, która miała trzy denka: w jednej części siedział Izaakowicz, w drugiej zaś części - tam, gdzie szpunt - była woda. Nie można było bowiem inaczej uciec z miasta. W ten więc sposób opuścił ziemię grecką. Gdy cesarz dowiedział się o tym, nakazał go odnaleźć. Poczęli więc [słudzy] szukać go w wielu miejscach. I weszli na pokład tego statku, na którym przebywał, i przeszukiwali wszystkie miejsca. Wyciągali szpunty z beczek, a widząc wypływającą [z nich] wodę, odeszli i nie odnaleźli $\mathrm{go}^{5}$.

\footnotetext{
1 Aleksy III Angelos (ok. 1153-1211) - cesarz bizantyński w latach 1195-1203. Przejął władzę w efekcie zamachu stanu, zdetronizowawszy swojego młodszego brata Izaaka II Angelosa, którego następnie kazał uwięzić i oślepić.

${ }^{2}$ Izaak II Angelos (ok. 1156-1204) - cesarz bizantyński w latach 1185-1195. Odsunięty od władzy przez swojego starszego brata, odzyskał tron 1 sierpnia 1203 r. po ucieczce Aleksego III z Konstantynopola, będącej konsekwencją działań wojennych, podjętych przez uczestników czwartej wyprawy krzyżowej. Od tego dnia formalnie dzielił rządy nad cesarstwem ze swoim synem, Aleksym IV. Został pozbawiony tronu 28 stycznia 1204 r. przez Aleksego V Dukasa Murzuflosa, a nie - jak podaje nowogrodzka opowieść - własnego syna.

${ }^{3}$ Aleksy IV Angelos (ok. 1182-1204) - cesarz bizantyński od 1 sierpnia 1203 r. do 28 stycznia 1204 roku. Zdetronizowany przez Aleksego V Dukasa Murzuflosa, został przez niego zamordowany już w następnym miesiącu - o czym informuje nas m.in. autor niniejszego zabytku.

${ }^{4} \mathrm{O}$ wykupieniu w latach 80 . XII w. Aleksego przez Izaaka II z niewoli muzułmańskiej wspominają również źródła zachodnie. Robert de Clari 1997, s. 31: „Potem ogarnęła go [Izaaka - przyp. ZB] bardzo wielka potrzeba zobaczenia swojego brata, który był w więzieniu u pogan; wziął posłów, wysłał ich w poszukiwaniu brata (...) poprosili Saracenów [aby go uwolnili], a Saraceni usłyszeli, że młodzieniec był bratem cesarza Konstantynopola, zażądali bardzo wysokiego okupu (...) tedy posłowie dali im tyle złota i srebra, ile zażądali”. Geoffroy de Villehardouin 2003, s. 29: „miał on [Izaak przyp. ZB] brata, którego imię było Aleksy, którego wykupił z tureckiej niewoli”.

${ }^{5}$ Fragment relacji dotyczący ucieczki młodego Aleksego z bizantyńskiej stolicy sprawia wrażenie anegdoty, zasłyszanej przez autora źródła lub jednego z jego informatorów na konstantynopolitańskiej ulicy. Niketas Choniates podaje, iż syn Izaaka opuścił miasto nad Bosforem na pizańskim okręcie
} 
4. W ten to sposób zbiegł Izaakowicz i przybył do cesarza niemieckiego Filipa ${ }^{6}$, do swojego szwagra i swojej siostry ${ }^{7}$. Cesarz niemiecki zwrócił się do papieża, do Rzymu i postanowili obaj, że nie będą walczyć przeciwko Carogrodowi, lecz „skoro Izaakowicz powiedział: 'wszyscy w mieście Konstantyna pragną mojego panowania', posadziwszy go na tronie, wyruszcie na pomoc Jerozolimie. Jeśli zaś go [w Konstantynopolu] nie zechcą, przyprowadźcie go z powrotem do mnie. Szkody zaś nie wyrządzajcie ziemi greckiej”.

5. Łacinnicy ${ }^{9}$ zaś i wszyscy ich dowódcy ukochali złoto i srebro, o których prawił im Izaakowicz, a o nakazach cesarza i papieża zapomnieli. Najpierw, przybywszy do [przystani] $\mathrm{Sud}^{10}$, rozerwali żelazne łańcuchy, a przystąpiwszy do [oblężenia] miasta, wrzucili ogień w czterech miejscach, w świątynie. Cesarz Aleksy, ujrzawszy płomienie, nie zorganizował obrony przeciwko nim, lecz przywoławszy brata Izaaka, którego oślepił, posadził go na tronie i rzekł: „Nawet jeśli ty to uczyniłeś, bracie, wybacz mi, a oto twoje cesarstwo". Po czym uciekł z miasta ${ }^{11}$.

(Nicetas Choniates 1975, s. 536). Geoffroy de Villehardouin relacjonuje te wydarzenia, co niezwykle ciekawe, w bardzo podobny sposób jak twórca ruskiej opowieści: „Ten syn [Aleksy - przyp. ZB] uciekł z więzienia i zbiegł na jednym okręcie do miasta nad morzem, które nazywa się Ankona. Tak on udał się [stamtąd] do króla Filipa Niemieckiego, który miał za żonę jego siostrę" (s. 29).

${ }^{6}$ Filip Szwabski (1177-1208) - syn cesarza Fryderyka I Barbarossy z dynastii Hohenstaufów, król Niemiec w latach 1198-1208 oraz książę Szwabii w latach 1196-1208. Źródło ruskie tytułuje go cesarzem, choć w rzeczywistości nigdy nie udało mu się zdobyć tej godności. Po śmierci jego starszego brata, Henryka VI (1165-1197) tron cesarski pozostawał nieobsadzony aż do roku 1209, w którym papież Innocenty III koronował w Rzymie Ottona IV Welfa.

7 Irena Angelos (ok. 1181-1208) - córka cesarza bizantyńskiego Izaaka II, siostra Aleksego IV. W 1197 r. została żoną króla Filipa Szwabskiego. Zdaniem niektórych badaczy wywierała realny wpływ na politykę swojego męża wobec Bizancjum, skłaniając go do okazania pomocy zdetronizowanemu ojcu i „wygnanemu” bratu w odzyskaniu konstantynopolitańskiego tronu (Meschini 2007, s. 60).

${ }^{8}$ Innocenty III (ok. 1160-1216) - papież rzymski w latach 1198-1216. W rzeczywistości pozostawał w otwartym konflikcie z królem Filipem, którego miał nawet obłożyć klątwą w 1201 roku. Wspierał natomiast jego politycznego rywala - Ottona IV Welfa. Przypisywane przez Nowogrodzianina papieżowi i cesarzowi słowa, aby rycerze wyruszający pod Konstantynopol nie wyrządzali zła chrześcijańskim mieszkańcom Bizancjum, pojawiają się również w jednym z listów Innocentego III do krzyżowców: Nec videntes terras Christianorum nec laedentes in aliquo (Innocentius III, CLXII, Comitibus, baronibus et allis crucesignatis, PL 214, col. 1180-1181).

${ }^{9} \mathrm{~W}$ tekście staroruskim pojawia się termin $\boldsymbol{\Phi}_{\rho \AA 3 \mathbf{s}}$, oznaczający w dosłownym thumaczeniu Franków. Określenie to odnaleźć można na kartach wielu średniowiecznych tekstów słowiańskich, zarówno proweniencji ruskiej, jak i bałkańskiej (m.in. serbskiej). Używano go w odniesieniu do różnych ludów zachodnioeuropejskich, których przedstawiciele byli „łacinnikami”, tj. chrześcijanami obrządku łacińskiego, rzymskiego (Naumow i Stradomski 2005, s. 238).

${ }^{10} \mathrm{Sud}\left(\mathbf{G o y}_{\mathbf{A}} \mathbf{z} \mathbf{\mathbf { z }}\right.$ - najprawdopodobniej staroruskie określenie przystani w zatoce Złoty Róg, łączącej się z cieśniną Bosfor na północnych rubieżach Konstantynopola. Termin ten pojawia się m.in. na kartach Powieści minionych lat oraz niektórych tekstów hagiograficznych, poświęconych księżnej kijowskiej Oldze. Złoty Róg zamykano na czas oblężenia żelaznym łańcuchem, przeciąganym na wysokości wieży Galata na północnym brzegu. Krzyżowcom udało się go rozerwać 10 lipca 1203 r., po kilku dniach walki (Pentek 2004, s. 51; Pentek 2005, s. 80).

${ }^{11}$ Aleksy III Angelos uciekł z Konstantynopola późnym wieczorem 17 lipca 1203 r., obawiając się, że przypuszczony przez krzyżowców szturm zakończy się upadkiem bizantyńskiej stolicy. Fakt 
6. I spalone zostało miasto i kościoły niewyrażalnej piękności, których liczby nawet nie możemy wypowiedzieć. I spłonął narteks Hagii Sofii, w którym zostali wyobrażeni wszyscy patriarchowie ${ }^{12}$, i hipodrom ${ }^{13}$, i [wszystko aż] do morza. Po drugiej zaś stronie spłonął [obszar] aż do ufortyfikowań pałacu cesarskiego ${ }^{14}$ i do [przystani] Sud. 7. Wtedy też wyruszył Izaakowicz w pościg za cesarzem Aleksym wraz z łacinnikami, lecz nie dopędził go i powrócił do miasta. Przegnał ojca z tronu i sam został cesarzem: „ty jesteś ślepy, jak więc mógłbyś dzierżyć władzę cesarską - ja jestem cesarzem!". Po tym cesarz Izaak, bolejąc wielce nad [losem] miasta i swojego cesarstwa, i nad grabieżą monasterów, które [były zmuszone]

ten odnotowuje również Geoffroy de Villehardouin (s. 70), Robert de Clari (s. 52) oraz Niketas Choniates, który wprost oskarża władcę o tchórzostwo (s. 546-547). Aleksy III po opuszczeniu Konstantynopola używał nadal tytułu cesarskiego, co komplikowało sytuację polityczną jego następców na bizantyńskim tronie. Co znamienne, analizowana opowieść nie wspomina o tym, dokąd udał się pozbawiony tronu cesarz. Warto wszak mieć na uwadze fakt, że w późniejszej ruskiej tradycji historiograficznej (reprezentowanej m.in. przez Latopis hustyński) pojawiła się legenda o ucieczce Aleksego III Angelosa na Ruś, na dwór księcia halickiego Romana Mścisławowicza. Jak wykazał Hieronim Grala, przekaz ten nie znajduje potwierdzenia w wiarygodnym materiale źródłowym (Grala 1986, s. 639-661). Podobne poglądy prezentuje Vitaliy Nagirnyy (Nagirnyy 2011, s. 100-109). Sceptycznie nastawiony do tezy o wizycie cesarza bizantyńskiego w Haliczu jest także Dariusz Dąbrowski (Dąbrowski 2012, s. 31). Odmiennie na tę kwestię zapatruje się natomiast Aleksander Maiorov, dopuszczający możliwość udania się Aleksego III Angelosa na Ruś (Майоров 2011, s. 193-220; Maiorov 2016, s. 18).

${ }^{12} \mathrm{O}$ istnieniu galerii wizerunków patriarchów i cesarzy w świątyni Hagia Sofia informuje też w swym itinerarium Dobrynia Jadrejkowicz (Antoni z Nowogrodu), zwiedzający bizantyńską stolicę ok. 1200 roku. Zdaniem wielu badaczy, autorzy ruscy mieli na myśli narteks lub południową galerię kościoła, ozdobioną mozaikami z wyobrażeniami cesarzy. Thomas F. Madden wysunął przypuszczenie, że twórca prezentowanej tu opowieści opisał raczej odkryte atrium po północno-zachodniej stronie świątyni, w którym znajdowała się fontanna kryta kopułą, na której przedstawiono Chrystusa w towarzystwie apostołów i cesarzy bizantyńskich (Madden 1991/1992, s. 78). Jest jednak mało prawdopodobne, by Nowogrodzianie, dość dobrze obeznani z kanonami sztuki wschodniochrześcijańskiej, nie rozpoznali - jak chce T.F. Madden - wizerunku Chrystusa i apostołów.

${ }^{13}$ Hipodrom - jeden z najstarszych obiektów świeckich w Konstantynopolu, pamiętający czasy założenia miasta. Budowlę tę wzorowano na Circus Maximus w Rzymie. Odbywały się w niej przede wszystkim wyścigi konnych zaprzęgów.

${ }^{14} \mathrm{Z}$ toku narracji prezentowanego tu utworu można odnieść wrażenie, iż wszystkie te zniszczenia spowodowane były przez jeden pożar, wywołany przez krzyżowców rychło po wpłynięciu ich okrętów w zatokę Złoty Róg. W rzeczywistości miały miejsce dwa pożary: pierwszy, w dniach 17-18 lipca 1203 r. rozgorzał w północno-zachodniej części miasta, między Blachernami a monasterem Chrystusa Dobroczyńcy, drugi zaś - o wiele potężniejszy i tragiczniejszy w skutkach - wybuchnął 19 sierpnia 1203 r. i trwał kilka dni, pochłaniając znaczne połacie metropolii: od rejonów położonych nad Złotym Rogiem, przez najbardziej reprezentacyjną część stolicy (z Forum Konstantyna, docierając do zachodnich ścian Hagii Sofii i hipodromu), aż po port Zofii i port Teodozjusza na południu. Nowogrodzka opowieść w miarę precyzyjnie określa więc obszar zniszczony wskutek pożarów. W opisie północnych

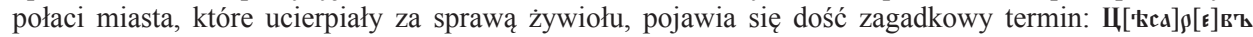
затвор'z. Zdecydowałam się przetłumaczyć go tak, jakby odnosił się do pałacu cesarskiego w Blachernach. Podobnie uczynili m.in. Robert Michell i Nevill Forbes, Jared Gordon, Sylvain Patri, a także Joachim Dietze i Dietrich Freydank (odnotowawszy wątpliwość tej interpretacji). O.W. Tworogow, bazując na tezach N.A. Mieszczerskiego, skłonny jest natomiast uznawać wspomnianą frazę za określenie żelaznego łańcucha, zamykającego zatokę Złoty Róg. 
oddawać łacinnikom złoto i srebro, przyrzeczone $\mathrm{im}^{15}$, rozchorowawszy się, został mnichem i odszedł z tego świata.

8. Po śmierci Izaaka ludzie powstali przeciwko jego synowi za spalenie miasta i za grabież dóbr monasterskich. Zebrało się pospólstwo i przyciągało znacznych mężów, rozważając wraz z nimi, kogo ustanowić cesarzem. Wszyscy chcieli Ra$\operatorname{dinosa}^{16}$, on jednak nie pragnął władzy cesarskiej i ukrywał się przed nimi, przebrawszy się w czarne [mnisze] szaty. Pochwyciwszy jego żonę, przywiedli ją do Hagii Sofii i usilnie naciskali na nią: „Powiedz nam, gdzie jest twój mąż”. Ona jednak nie wydała swojego męża. Następnie pochwycili człowieka o imieniu Mikołaj $^{17}$, żołnierza, włożyli na niego [cesarski] wieniec bez udziału patriarchy i przebywali z nim w Hagii Sofii przez sześć dni i sześć nocy.

9. Cesarz Izaakowicz przebywał zaś w Blachernach i pragnął wprowadzić łacinników do miasta w tajemnicy przed wielmożami. Ci jednak, dowiedziawszy się [o tym], ułagodzili cesarza i nie pozwolili mu wpuścić łacinników, mówiąc: „my jesteśmy z tobą". Następnie wielmoże, przestraszywszy się wprowadzenia łacinników, porozumiawszy się z Murzuflosem ${ }^{18}$, pojmali cesarza Izaakowicza, a na Murzuflosa włożyli [cesarski] wieniec - tegoż Murzuflosa uwolnił ongiś z więzienia Izaakowicz i odebrał od niego przysięgę, iż nie będzie on za rządów Izaakowicza dążył do władzy cesarskiej, lecz [będzie] czuwał nad nim.

15 Młody Aleksy Angelos, pragnąc zachęcić zachodnioeuropejskie rycerstwo do okazania mu pomocy w zdobyciu cesarskiego tronu, złożył na początku 1203 r. wiele daleko idących obietnic. Geoffroy de Villehardouin relacjonuje, iż zobowiązał się on wypłacić krzyżowcom 200 tysięcy srebrnych marek oraz zapewnić wyżywienie ich wojskom. Ponadto przyrzekł, że albo osobiście przyłączy się do planowanej przez nich wyprawy do Egiptu, albo wystawi na swój koszt dziesięciotysięczny korpus, który będzie finansował przez jeden rok. Pretendent do cesarskiego diademu miał również dożywotnio utrzymywać oddział 500 rycerzy „za morzem”, tj. w Outremer (s. 38). Jak ubolewa Niketas Choniates (s. 555-556), obietnice te zostały złożone lekkomyślnie i aby ich dotrzymać, ojciec Aleksego, Izaak II zmuszony był naruszyć zasoby Kościoła. Posunięcie to stało się przyczyną niezadowolenia mieszkańców Konstantynopola i doprowadziło do upadku obu cesarzy.

${ }^{16}$ Radinos - trudno o jednoznaczną identyfikację tej postaci, gdyż o kandydacie do cesarskiego diademu o takim imieniu nie wspomina żadne inne źródło poza prezentowaną tu opowieścią. Niektórzy badacze próbują utożsamiać tę osobę ze wzmiankowanym przez Niketasa Choniatesa (s. 507) sebastosem Konstantynem Radenosem, stronnikiem cesarza Aleksego III Angelosa.

${ }_{17}$ Mikołaj Kanabos (zm. 5 lutego 1204) - młody arystokrata bizantyński, wbrew swej woli obwołany cesarzem 25/27 stycznia 1204 r. przez mieszkańców Konstantynopola, zgromadzonych w kościele Hagia Sofia. Po objęciu rządów przez Aleksego V Dukasa Murzuflosa został uwięziony i stracony. O epizodzie tym wspomina w swej kronice Niketas Choniates (s. 562-564).

18 Aleksy V Dukas Murzuflos (ok. 1140-1205) - cesarz bizantyński od 5 lutego do 13 kwietnia 1204 roku. Uwięziony przez Aleksego III Angelosa w 1200 r. za udział w nieudanym zamachu stanu, zainicjowanym przez Jana Komnena „Tłustego”, wolność odzyskał - tak jak podaje źródło nowogrodzkie - na rozkaz Aleksego IV i jego ojca Izaaka II w 1203 r., rychło po objęciu przez nich władzy cesarskiej. 28 stycznia 1204 r., wykorzystując nastroje antyłacińskie panujące w mieście, Murzuflos odsunął obu monarchów od rządów i pozbawił wolności. 5 lutego - jak odnotowuje m.in. prezentowana tu opowieść - proklamował się cesarzem. Izaak II zmarł wkrótce po tych wydarzeniach w wiezieniu, Aleksy IV został zaś zamordowany na wyraźny rozkaz nowego cesarza. Murzuflos uciekł z Konstantynopola 9 kwietnia 1204 r., kilka dni przed jego zdobyciem przez uczestników czwartej wyprawy krzyżowej. 
10. Murzuflos zaś posłał do Mikołaja i do ludzi [zebranych] w Hagii Sofii [wiadomość]: „Pochwyciłem wroga waszego Izaakowicza, to ja jestem waszym cesarzem, a Mikołaja czynię pierwszym wśród wielmożów, niech zdejmie z siebie wieniec". Wszyscy ludzie nie pozwolili mu zdjąć wieńca, lecz tym bardziej poprzysięgli sobie: „kto odstąpi od Mikołaja, niech będzie przeklęty”. Tego samego dnia, doczekawszy nocy, rozbiegli się [jednak] wszyscy, a Mikołaja pochwycili. Żonę zaś jego ujął Murzuflos i wtrącił ją do więzienia. Aleksego Izaakowicza też osadził w twierdzy, a on sam, Murzuflos został cesarzem w dniu 5 lutego, mając nadzieję wygubić łacinników.

11. Łacinnicy jednak, dowiedziawszy się o tym, że Izaakowicz został pojmany, grabili terytoria pod miastem, prosząc Murzuflosa: „oddaj nam Izaakowicza, a odejdziemy do cesarza niemieckiego, przez którego zostaliśmy tu przysłani, a twoim będzie jego [tj. Aleksego] cesarstwo". Murzuflos i wszyscy wielmoże nie wydali go jednak żywego. Uśmiercili Izaakowicza i rzekli łacinnikom: „Martwy jest, przyjdźcie i zobaczcie go". 12. Wtedy łacinnicy byli rozżaleni swoim nieposłuszeństwem - nie tak wszak nakazał im [działać] cesarz niemiecki i papież rzymski, wyrządzili zło Carogrodowi. Mówili między sobą: „Nie mamy już Izaakowicza, z którym to przyszliśmy. Lepiej nam więc umrzeć pod Carogrodem, aniżeli odejść ze wstydem". I od tej chwili zaczęli się sposobić do szturmu na miasto.

13. Postanowili [atakować] tak, jak poprzednio, na okrętach z mostkami na rejach (?), na innych okrętach ustawili zaś tarany i drabiny, a na jeszcze innych zamyślili pozawieszać beczki wypełnione smołą [do miotania] na miasto ${ }^{19}$. I zapaliwszy drzazgi, wyrzucili je na zabudowania - tak jak poprzednio - podpalili miasto $^{20}$. Przystąpili do szturmu $\mathrm{w}$ dniu 9 kwietnia, w piątek, w piątym tygodniu postu i nie zdołali nic wyrządzić miastu. Zostało zaś zabitych nieomal 100 łacinników. I stali tu łacinnicy trzy dni. W poniedziałek zaś, w szóstym tygodniu Wielkiego Postu, o wschodzie słońca przystąpili [do szturmu] na miasto, naprzeciwko

${ }^{19}$ Łacinnicy przystąpili do konstruowania maszyn oblężniczych, być może, już 10 marca 1204 r. Ich szczegółowy opis zawarł w swojej narracji Robert de Clari: „,Wenecjanie i Francuzi przygotowywali i uzbrajali swe okręty; Wenecjanie zbudowali mostki na swoich nefach, a Frankowie zbudowali inne machiny oblężnicze, które nazwali kotkami i furami i świniami, aby podkopać i zburzyć mury; a Wenecjanie wzięli deski z domów i szczelnie je dopasowali, pokryli pokrycia swoich okrętów, a potem wzięli winorośla i przykryli nimi deski, aby kamieniomioty nie mogły uszkodzić okrętów i roznieść ich na kawałki” (s. 66).

${ }^{20}$ Zdaniem Thomasa F. Maddena, trzeci pożar Konstantynopola, spowodowany działaniami krzyżowców, miał miejsce w nocy z 12 na 13 kwietnia 1204 roku. Objął znacznie mniejsze połacie miasta niż poprzednie katastrofy tego rodzaju - stosunkowo wąski pas zabudowań wzdłuż Złotego Rogu, w okolicy monasteru Chrystusa Dobroczyńcy (Madden 1991/1992, s. 85, 93). Michael Angold twierdzi natomiast, że uczestnicy czwartej wyprawy krzyżowej, przerwawszy linię obrony w rejonie pałacu w Blachernach, podpalili całą tę dzielnicę (Angold 2006, s. 119). 
[monasteru] świętego Zbawiciela zwanego Euergetes ${ }^{21}$ i [bramy] Eis Pegas ${ }^{22}$, rozstawili [swe siły] aż do Blachern. 14. Przystąpili na 40 wielkich okrętach, były zaś między nimi połączone rzemieniami [ze sobą]23, na których znajdowali się jeźdźcy odziani w pancerz i ich konie. Inne zaś ich okręty i galery stały z tyłu, z obawy przed podpaleniem, gdyż poprzednim razem Grecy wypuścili na nie 10 okrętów z ogniem, złapawszy w żagle sprzyjający wiatr, o północy na dzień św. Bazylego ${ }^{24}$. Nie zdołali nic [uczynić] okrętom łacinników, ponieważ uprzedził

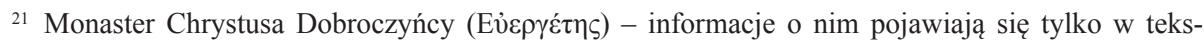
tach późnośredniowiecznych. Oprócz prezentowanej tu opowieści obiekt o tej nazwie wzmiankuje kilka źródeł bizantyńskich. Niewielki passus poświęcił mu również w swoim itinerarium diakon Zosym, zwiedzający Konstantynopol w latach 1419-1422. Ponieważ większość istniejących przekazów zawiera informację, iż w murach monasteru Chrystusa Dobroczyńcy znajdowały się szczątki św. Teodozji, badacze utożsamiają zazwyczaj omawiany obiekt z występującym znacznie częściej w materiale źródłowym kościołem/monasterem poświęconym tej świętej. George P. Majeska przypuszcza, że budowla dedykowana Chrystusowi Dobroczyńcy i świątynia św. Teodozji mogły być de facto częściami jednego kompleksu monastycznego, w którym imię Zbawiciela nosiłby konwent męski, świętej zaś - żeński (Majeska 1984, s. 347-349). Obiekt ten powstał najprawdopodobniej w XI-XII wieku. Znajdował się w północnej części Konstantynopola, nieopodal Złotego Rogu (Kompa 2011, s. 150-151).

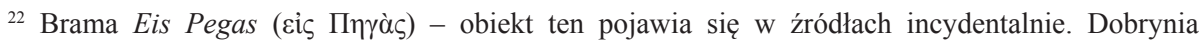
Jadrejkowicz (Antoni z Nowogrodu) wspomina w swym itinerarium kilkakrotnie dzielnicę o tej nazwie (Испигас). Brama Eis Pegas znajdowała się w murach miejskich nad Złotym Rogiem, nieopodal kościoła św. Teodozji. Utrwalona m.in. przez ruskich podróżników popularna nazwa obiektu wiąże się z jego położeniem - przez niniejszą bramę można było wyjść ku okolicy Pegae, znajdującej się na przeciwległym brzegu zatoki. W źródłach zachodnich obiekt ten nazywany jest Porta Puteae lub Porta del Pozzo. Współczesnie: Cibali Kapısı (Van Millingen 1899, s. 209-211; Janin 1950, s. 271-272).

${ }^{23} \mathrm{~W}$ wersji oryginalnej tekstu pojawia się tu trudny do przetłumaczenia wyraz излєнєнани. Ропіеważ niniejsza opowieść jest jedynym zachowanym utworem staroruskim, w którym odnaleźć można wspomniany termin, wokół jego znaczenia toczyła się w literaturze przedmiotu ożywiona dyskusja. Powstało również kilka wariantów przekładu kłopotliwego passusu. N.A. Mieszczerski utrzymywał, że pojawienie się w tekście zabytku słowa, niemającego analogii w żadnym innych utworze staroruskim, jest konsekwencją zwykłej pomyłki kopisty, sporządzającego odpis synodalny Latopisu nowogrodzkiego pierwszego. Pierwotnie we wskazanym miejscu miał się bowiem znajdować, nieznany północnoruskiemu skrybie, termin dromony, zapożyczony przez autora źródła np. z przekazu Niketasa Choniatesa (Мещерский 1954, s. 126; Мещерский 1956, s. 175-176). Zgodnie z tą interpretacją Dietrich Freydank i O.W. Tworogow przetłumaczyli wątpliwy fragment: „między nimi były i dromony”. Z tezą Mieszczerskiego spróbował polemizować N.F. Pronczatow, wskazując, iż wyraz изљємєнани można wywieść od staroruskiego rzeczownika ९єнєнь. Zdaniem tego badacza, analizowany fragment należałoby zatem rozumieć tak, iż okręty krzyżowców były „obrzemieniowane”, tj. obwiązane skórami w celu zabezpieczenia ich przed „ogniem greckim” (Прончатов 1967, s. 325-327). Biorąc jednak pod uwagę fakt, iż Geoffroy de Villehardouin (s. 91) i Robert de Clari (s. 66) mówią o tym, że okręty łacinników były złączone ze sobą burta w burtę, za najwłaściwszą lekcję należałoby uznać tę, która została - jak dotąd - przyjęta przez większość tłumaczy (Roberta Michella i Nevilla Forbesa, Joachima Dietze, Jareda Gordona i Sylvaina Patri): „,były między nimi połączone rzemieniami [ze sobą]”.

${ }^{24}$ Autor opowieści wprowadza tu retrospekcję, opisując zdarzenie, do którego doszło 1 stycznia 1204 roku. Bizantyńczycy podjęli wówczas próbę zniszczenia floty weneckiej, skierowawszy na nią 17 własnych okrętów, które uprzednio podpalili. Michael Angold jest zdania, że od całkowitej klęski uchroniły krzyżowców ich umiejętności i zdyscyplinowanie, nie zaś - jak chce nowogrodzki dziejopis - fakt, iż zostali wcześniej uprzedzeni o zamiarach wroga przez Aleksego IV (Angold 2006, s. 114). Tak relacjonuje ten incydent Geoffroy de Villehardouin: „I wówczas Grecy wymyślili bardzo wielką pułapkę: gdyż wzięli 17 wielkich nef, napełnili je wszystkie wielkimi kawałkami drewna i palnymi materiałami, i pakułami, i smołą, i beczkami, i oczekiwali, aż powiał bardzo silny wiatr z ich strony. 
ich wcześniej Izaakowicz, rozkazawszy Grekom zaatakować ich na okrętach dzięki temu nie zgorzeli łacinnicy.

15. A tak odbyło się zdobycie wielkiego Carogrodu: wiatr przygnał okręty pod mur miejski, a drabiny [tj. machiny oblężnicze] na nich były wyższe niż umocnienia miasta, niższe drabiny były zaś równe obwarowaniom. [Łacinnicy] razili z wyższych drabin Greków i Waregów, którzy byli na murach, kamieniami, strzałami i kopiami, z niższych zaś - zeszli na mury. I tak zdobyli miasto. 16. Cesarz Murzuflos pokrzepiał wielmożów i wszystkich ludzi, chcąc tu zorganizować obronę przeciwko łacinnikom, lecz nie usłuchali go i uciekli od niego wszyscy. Cesarz uszedł od nich [tj. łacinników] i dogonił ich [tj. Bizantyńczyków] na końskim $\operatorname{targu}^{25}$. I bardzo skarżył się na wielmożów i na wszystkich ludzi. Wtedy to cesarz uciekł z miasta wraz z patriarchą i ze wszystkimi wielmożami.

17. Łacinnicy weszli do miasta 12 kwietnia, w dzień świętego Bazylego Wyznawcy, w poniedziałek i zatrzymali się w miejscu, w którym przebywał cesarz grecki - w [monasterze] Świętego Zbawiciela ${ }^{26}$ i tu pozostali na noc. Nazajutrz zaś o wschodzie słońca weszli do Hagii Sofii. Odarli wrota i rozsiekali [je], ambonę zaś, okutą w całości srebrem i 12 filarów srebrnych, a cztery - od kiotu oraz templon rozbili. [Zniszczyli] 12 krzyży, które były nad ołtarzem, a między nimi szyszki jak drzewa wyższe od mężczyzny, i balustrady ołtarzowe między filarami,

I tej nocy, o północy podłożyli ogień na nefach i opuścili żagle na wiatr, a ogień rozpalił się bardzo wysoko, że wydawało się, że cała ziemia płonie. I tak popłynęły [te nefy] ku okrętom pielgrzymów; a w obozie podniósł się wrzask; i wszyscy chwytali za broń. Wenecjanie i wszyscy inni, którzy mieli statki, wbiegli na swe statki, i jęli je ratować z wielką żwawością" (s. 83-84). „Tak znosili tę próbę i obawy aż do jasnego dnia. Lecz dzięki Bogu, nie utracili nasi nic, prócz jednego pizańskiego nefa, który był pełen towarów; on spłonął w ogniu (...) Taką nagrodę dał im cesarz Aleksy za pomoc, którą mu okazali" (s. 94).

${ }^{25} \mathrm{~W}$ teście oryginalnym konstrukcja niniejszego zdania uległa zakłóceniu, najprawdopodobniej wskutek błędu kopisty. Zaproponowana przeze mnie interpretacja sensu passusu bazuje na przekładach niemieckich Dietricha Freydanka i Joachima Dietze, w których zastosowano, w moim odczuciu, rozwiązanie nadające sens tekstowi, a jednocześnie nieingerujące zbytnio w jego specyfikę. Trudno również ustalić, jakie miejsce w stolicy Bizancjum miał na myśli autor nowogrodzki, pisząc o końskim targu. Co ciekawe, określenie to pojawia się także na kartach itinerarium Dobryni Jadrejkowicza (Antoniego z Nowogrodu). Podróżnik ten lokalizuje koński targ między świątynią Hagia Sofia i kościołem Bogurodzicy przy Długim Portyku (Makros Embolos). W literaturze przedmiotu próbowano niekiedy identyfikować analizowany obiekt jako Forum Konstantyna lub hipodrom. Za tą drugą hipotezą może przemawiać wzmianka Geoffroya de Villehardouina, iż Aleksy Murzuflos uciekł przed łacinnikami do pałacu Bukoleon (s. 94).

${ }^{26}$ Kwatera główna Aleksego Murzuflosa znajdowała się w monasterze Chrystusa Wszechwidzą-

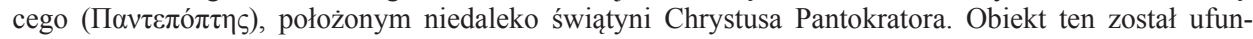
dowany w latach 80. XI w. z inicjatywy Anny Dalasseny, matki cesarza Aleksego I Komnena (Kompa 2011, s. 153-154). O tym, iż krzyżowcy, po wkroczeniu do Konstantynopola wieczorem 12 kwietnia 1204 r., postanowili zatrzymać się na nocleg w dawnej kwaterze Aleksego Murzuflosa, tj. monasterze Chrystusa Wszechwidzącego, informuje nas też Niketas Choniates (s. 570). Geoffroy de Villehardouin precyzuje, że czerwone namioty, pozostawione tam przez cesarza, zajął Baldwin z Flandrii (s. 95). 
a wszystko to srebrne ${ }^{27}$. Cudowny święty stół odarli z drogich kamieni i olbrzymich pereł, a sam [stół] nie wiadomo gdzie zapodziali. 18. [Zagrabili] 40 wielkich kubków, które były przed ołtarzem, żyrandole i świeczniki srebrne, których liczby nie możemy wypowiedzieć, oraz bezcenne naczynia świąteczne. Ewangeliarz ołtarzowy, czcigodne krzyże i bezcenne ikony - to wszystko odarli. Pod świętym stołem znaleźli zaś skrytkę z 40 kadziami czystego złota. W skarbcu, w murach i w skewofylakionie [zrabowali] nie wiedzieć ile złota i srebra, gdyż nie ma na to liczby, i [tyleż] bezcennych naczyń. 19. To wszystko, o czym opowiedziałem, było tylko w samej [Hagii] Sofii, a wszak splądrowali też [kościół] Świętej Bogurodzicy w Blachernach ${ }^{28}$, gdzie Duch Święty zstępował w każdy piątek. O innych kościołach nie może człowiek opowiedzieć, gdyż są niezliczone. Natomiast cudowną [ikonę] świętej Bogurodzicy Hodegetrii ${ }^{29}$, która chodziła po mieście, uchronił Bóg

27 Opis wystroju wnętrza przestrzeni ołtarzowej kościoła Mądrości Bożej zgadza się w ogólnych zarysach z relacjami wcześniejszych autorów bizantyńskich, m.in. Pawła Silencjariusza (VI w.). Warto go zestawić także z obrazem, wyłaniającym się z anonimowej opowieści o budowie świątyni Hagia

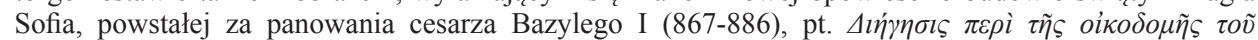

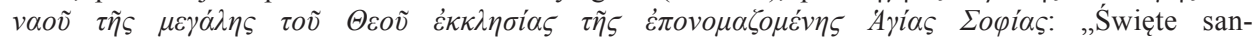
ktuarium wykonał zaś z jasnego srebra; kwadratowe płyty z marmuru i kolumny pokrył srebrem wraz z ich bramami; wszystko [było] srebrne i pozłacane. Cztery stoły ze srebra ustawił przy świętym ołtarzu na kolumnach i pozłocił. Siedem stopni [dla] kapłanów, na których zasiadają, wraz z tronem arcykapłana i czterema kolumnami ze srebra pozłocił, ustawiwszy z obu stron po dwie, przy wejściu do łukowatego przejścia, zwanego kyklios, które znajduje się pod stopniami. [Miejsce] to nazwał Świętym Świętych. Ustawił [w nim] potężne kolumny srebrno-złote z baldachimem (cyborium) i ornamentem z lilii. Baldachim zaś wykonał ze srebra i pokrył emalią. Na baldachimie umieścił kulę całą ze złota, o wadze 118 funtów i stojące złote lilie o wadze 6 funtów, na nich [zaś] złoty krzyż z drogimi i rzadkimi kamieniami, który osiągał ciężar 70 funtów złota" (Sawa 1991/1992, s. 421-422).

${ }^{28}$ Kościół Bogurodzicy w Blachernach - właściwie był to kompleks trzech budowli (Wielki Kościół, kaplica św. Relikwiarza i Święte Łaźnie), ufundowany w połowie V w. przez cesarzową Pulcherię, ukończony przez Leona I (457-474), a następnie gruntownie przebudowany po pożarze, który strawił przybytek ok. 1070 roku. Najcenniejszą relikwią przechowywaną w analizowanej świątyni była szata (maforion) Matki Bożej, sprowadzona do Konstantynopola z Ziemi Świętej w drugiej połowie $\mathrm{V}$ wieku. Znajdowała się tam również cudowna ikona Bogurodzicy. Wierzono, że blacherneńskie relikwie oraz wizerunek Marii kilkukrotnie ocaliły bizantyńską stolicę przed najazdem nieprzyjaciół, np. w 626 r. - przed Persami i Awarami, w 860 r. - przed Rusami (Leszka i Wolińska 2011, s. 140-142, 425-427). Nie jest jasne, czy przechowywana w Blachernach szata Matki Bożej została w całości wywieziona na Zachód po 1204 r., czy też jakiś jej fragment ostał się w Konstantynopolu. W XIV-XV w. o obecności interesującego nas tu artefaktu nad Bosforem wspominają tylko podróżnicy ruscy. Autor nowogrodzkiej opowieści pomija tę kwestię milczeniem. Na kartach Latopisu helleńskiego i rzymskiego drugiej redakcji oraz kilku kronik północnoruskich z XV-XVI w. pojawia się natomiast swoisty aneks, zawierający stwierdzenie, iż szata Bogurodzicy w okresie, w którym powstawał, znajdowała się nadal w Blachernach. Nie są natomiast jasne dalsze losy cudownej ikony Matki Bożej (Salamon 2005, s. 186-188).

${ }^{29}$ Autor opowieści ma tu na myśli cudowną ikonę Matki Bożej Hodegetrii, której autorstwo tradycja przypisywała samemu św. Łukaszowi. Pierwotnie miała się ona znajdować w monasterze Bogurodzicy Hodegon, ufundowanym w połowie V w. przez cesarzową Pulcherię (Leszka i Wolińska 2011, s. 143-144, 425). Autor opowieści informuje o ocaleniu artefaktu przed zniszczeniem po zajęciu Konstantynopola przez łacinników. Jego istnienie poświadczają też podróżnicy ruscy z XIV-XV w., m.in. przebywający nad Bosforem w 1348/1349 r. Stefan z Nowogrodu, opisujący barwnie wydarzenia towarzyszące procesji, odbywającej się we wspomnianym monasterze w każdy wtorek: „,we wto- 
z pomocą dobrych ludzi. Istnieje ona do dzisiaj i w niej pokładamy nadzieję. 20. Inne kościoły $\mathrm{w}$ mieście i poza miastem oraz monastery $\mathrm{w}$ mieście i poza miastem rozgrabili wszystkie - nie możemy podać ich liczby ani wypowiedzieć ich piękności. Mnichów, mniszki i duchownych obrabowali, a niektórych z nich - zabili. Greków zaś i Waregów, którzy pozostali w mieście, wygnali.

21. A oto imiona ich dowódców: pierwszy to marchio z Rzymu ${ }^{30}, \mathrm{z}$ miasta Bernu [tj. Werony], w którym żył ongiś zły poganin Dydryk ${ }^{31}$. A drugi to conte di Flandria $^{32}$, a trzeci - ślepy doża z wyspy [św.] Marka, Wenecji ${ }^{33}$. 22. Dożę tego

rek udaliśmy się do ikony procesyjnej świętej Bogurodzicy, którą to ikonę napisał ewangelista Łukasz, zerkając na samą Panią Dziewicę Bogurodzicę, kiedy jeszcze była żywa. Ikona ta jest wynoszona w każdy wtorek. Nadzwyczaj cudowny to widok: schodzą się tu wszyscy mieszkańcy z miast[a]. Ikona ta zaś jest bardzo wielka, kunsztownie oprawiona i śpiewacy śpiewają przed nią pięknie, a wszyscy mieszkańcy wołają z płaczem: Kyrie eleison! Postawią [ikonę] na barkach jednego stojącego człowieka, a on ręce wyciągnie jak ukrzyżowany i oczy mu uciekną pod powieki, aż strach patrzeć - i po dziedzińcu nim rzuca w tę i we w tę, niezwykle mocno nim kręci, a on nie ma świadomości, dokąd go ikona niesie. Potem inny [człowiek] ją chwyci i [dzieje się z nim] to samo, także i z trzecim i czwartym przechwytującym, i śpiewają oni wraz z kanonarchami pieśń wielką, a lud woła z płaczem: 'Panie, zmiłuj się'! Dwóch diakonów dzierży ripidiony, a inni [trzymają] przed ikoną kiot. Zdumiewający to widok: siedmiu lub ośmiu ludzi stawia [ikonę] na barki jednemu człowiekowi, a on z woli Bożej chodzi jakby bez brzemienia". O losach ikony Bogurodzicy Hodegetrii w epoce ikonoklazmu, na czas którego miała ona zostać ukryta w monasterze Chrystusa Pantokratora, opowiada krótki utwór, dołączony do tekstu prezentowanej tu narracji m.in. w Latopisie helleńskim i rzymskim. Jego autor poświadcza również, iż w późnym średniowieczu artefakt ten znajdował się w monasterze w Hodegon.

${ }^{30}$ Bonifacy z Montferratu (ok. 1140-1207) - jeden z przywódców czwartej wyprawy krzyżowej. Autor opowieści nie wymienia jego imienia, biorąc za nie pomyłkowo noszony przezeń tytuł, najprawdopodobniej już zasłyszany w zniekształconym brzmieniu. Bonifacy był markizem (wł. marchese, fr. marquis, niem. Margraf) Montferratu od 1192 roku. Po zdobyciu stolicy Bizancjum przez krzyżowców bez powodzenia pretendował do godności łacińskiego cesarza Konstantynopola. W latach 1204-1207 panował na zdobytych przez siebie obszarach Macedonii i Tesalii, tytułując się królem Tessaloniki.

${ }^{31}$ Dydryk z Bernu - postać pojawiająca się na kartach kilku eposów niemieckich, m.in. IX-wiecznej Pieśni o Hildebrandzie, sagi o Dydryku (Dietrichsage) oraz słynnej Pieśni o Nibelungach, powstałej na przełomie XII i XIII stulecia. Historycznym pierwowzorem tego bohatera był król Ostrogotów, Teodoryk Wielki (471-526). Bern to natomiast staroniemiecka nazwa Werony. Przyczyny, dla których autor prezentowanej tu opowieści skojarzył Bonifacego z Montferratu z Dydrykiem z Bernu, są dość niejasne.

32 Baldwin (1171-1205) - hrabia Flandrii (conte di Flandria) od 1195 roku. Autor ruskiej opowieści podaje noszony przez niego tytuł w postaci znacznie zniekształconej: Икондофъ Baldwin był jednym z najważniejszych przywódców czwartej krucjaty, ciesząc się wśród jej uczestników niezwykłym poważaniem. Po zdobyciu przez nich stolicy Bizancjum został obwołany pierwszym łacińskim cesarzem Konstantynopola. Stało się to - jak informuje nas nowogrodzkie źródło 9 maja 1204 roku. Uroczysta koronacja miała natomiast miejsce kilka dni później - 16 maja 1204 roku.

${ }^{33}$ Henryk Dandolo (ok. 1107-1205) - doża wenecki w latach 1192-1205. Podczas oblężenia stolicy Bizancjum przez krzyżowców był już człowiekiem w podeszłym wieku. Był również niewidomy. Geoffroy de Villehardouin (s. 28) opisuje jego ułomność w bardzo podobny sposób jak autor nowogrodzkiej relacji: „był starym człowiekiem i miał w obliczu piękne oczy, a nic nie widział, gdyż stracił wzrok przez ranę, którą miał w głowie". Ani ten, ani żaden inny współczesny dziejopis (łącznie z Niketasem Choniatesem, przypisującym weneckiemu doży żywienie szczególnej nienawiści względem Bizantyńczyków) nie wiąże jednak utraty wzroku przez Henryka z oślepieniem na rozkaz 
oślepił ongiś cesarz Manuel ${ }^{34}$, gdyż wielu mędrców błagało go: „Jeśli tego dożę wypuścisz [całego i] zdrowego, to wiele zła wyrządzi on twojemu cesarstwu". Cesarz więc, nie chcąc go zabijać, rozkazał oślepić mu oczy szkłem. I jego oczy były jakby nieuszkodzone, ale nie widział nic. To ów doża planował wiele ataków na miasto i wszyscy go słuchali, i do niego należały wielkie okręty, z których zdobyto miasto. 23. Łacinnicy stali pod Carogrodem od grudnia do kwietnia, aż miasto zostało zdobyte. Zaś 9 dnia miesiąca maja ustanowili własnego cesarza łacinnika, conte di Flandria [Baldwina] z pomocą swoich biskupów i rozdzielili władzę między siebie. Cesarzowi [przypadło] miasto, marchio [Bonifacemu] - sąd, a doży - dziesięcina. I w ten to sposób zostało zgubione cesarstwo chronionego przez Boga Konstantynopola i ziemia grecka, z powodu konfliktu między cesarza$\mathrm{mi}^{35}$. Teraz władają nią łacinnicy.

ANEKS:

OPOWIEŚĆ O IKONIE BOGURODZICY HODEGETRII I SZACIE MATKI BOŻEJ W BLACHERNACH

Przytoczony fragment pochodzi z Latopisu helleńskiego i rzymskiego drugiej redakcji, wg odpisu БАН, 33.8.13, datowanego na ostatnią ćwierć XV wieku. Znajduje się na kartach 296d-297b, bezpośrednio po tekście opowieści o zdobyciu Konstantynopola przez uczestników czwartej wyprawy krzyżowej w 1204 roku.

cesarza Manuela I. Oprócz źródła ruskiego wspomina o tym jedynie w swej kronice doża Andrzej Dandolo (1306-1354). Steven Runciman wysunął przypuszczenie, że Henryk przebywał w latach 70. XII w. z misją dyplomatyczną w Konstantynopolu i utracił tam wzrok wskutek ulicznej bijatyki (Runciman 1987, s. 117). Tezę tę zanegował Thomas F. Madden, podkreślając, iż nie sposób dokładnie ustalić, kiedy i w jakich okolicznościach Henryk stał się niewidomy, autor nowogrodzkiej opowieści i Andrzej Dandolo musieli zaś opierać swój przekaz na wspólnym źródle - pogłoskach krążących po Konstantynopolu (Madden 1993, s. 179-185). Nie ulega natomiast najmniejszej wątpliwości rola, odegrana przez wenecką flotę w trakcie czwartej wyprawy krzyżowej.

${ }^{34}$ Manuel I Komnen (1118-1180) - cesarz bizantyński w latach 1143-1180. Za jego panowania w istocie doszło do konfliktu z Wenecją, którego konsekwencją było zerwanie stosunków dyplomatycznych i handlowych między cesarstwem a republiką św. Marka. 12 marca 1171 r. wszyscy Wenecjanie przebywający na obszarze Bizancjum zostali aresztowani, a ich majątki uległy konfiskacie. Przywileje gospodarcze republiki św. Marka zostały odnowione dopiero w 1198 r., za panowania Aleksego III Angelosa (Quirini-Popławska 2005, s. 16-18).

35 Wyczulenie na niebezpieczeństwa, które mogą wyniknąć dla państwa z powodu konfliktu między osobami sprawującymi władzę lub wskutek rywalizacji w rodzie panującym, jest cechą charakterystyczną literatury staroruskiej w XII-XIII wieku. Zainteresowanie twórców z tego obszaru wspomnianą problematyką wynikało bezsprzecznie z sytuacji na Rusi - postępującego rozdrobnienia politycznego, osłabienia autorytetu wielkiego księcia kijowskiego i ogólnej destabilizacji stosunków między przedstawicielami coraz bardziej rozrodzonej dynastii Rurykowiczów. Los cesarstwa bizantyńskiego w 1204 r. miał zapewne stanowić pouczające exemplum dla ruskiego czytelnika, zwłaszcza jeśli wywodził się on z wyższych warstw społecznych. Przestrogi przed zgubnymi konsekwencjami bratobójczych waśni pojawiają się w XII-XIII w. nie tylko na kartach latopisów, ale też tekstów o charakterze moralizatorskim, wychodzących spod pióra władców, np. słynnego Pouczenia Włodzimierza II Monomacha (1053-1125) czy rad księżnej włodzimierskiej Marii (ok. 1160-1206) dla swoich synów. 
Przedrukowano za: Летописеи Еллинский и Римский, vol. I, Текст, red. O.В. Творогов, Санкт-Петербург 1999, s. 510-511.

(fol. 296d) О икон' Богояодици.

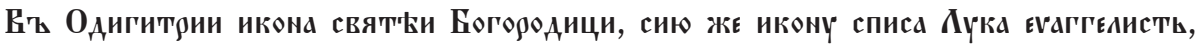
износят юо в' всякыи вт[орни]К на нонастырь чюодеса творить и дО сего дни,

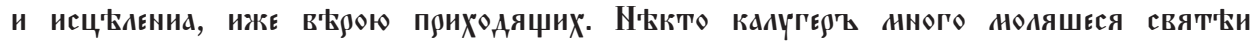
Богояодици: Госпождє, яви яи ся, какова єси Была въ плоти. И Бысть єну Гдас:

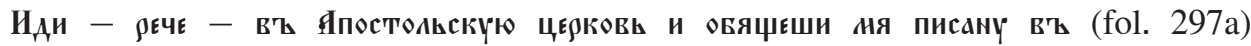

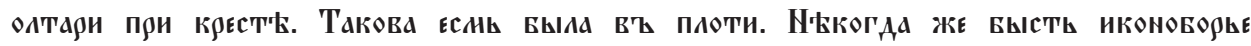

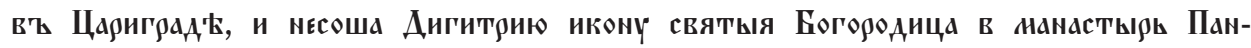

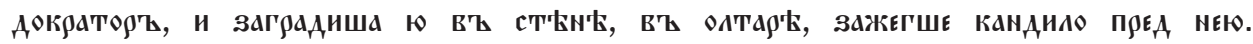

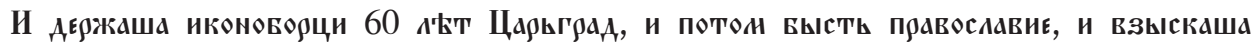

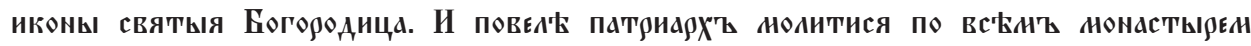

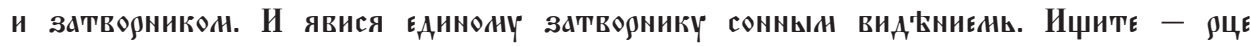
- иконы святыя Богородица въ Пандократори. И аБие оврБтоша юо, и кандидо не

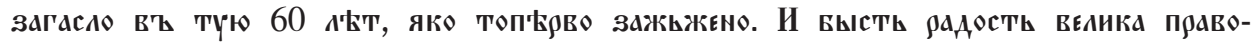

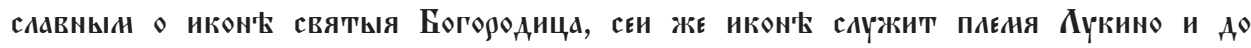
cє下o Aни.

0 риз'т.

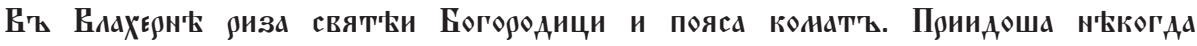

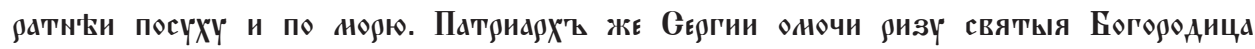

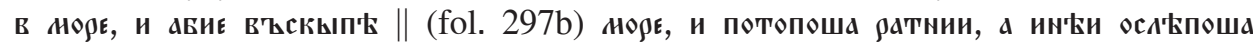
и пов'ьгоша от страха.

O ikonie Bogurodzicy.

W [monasterze] Hodegetrii jest ikona świętej Bogurodzicy, którą to ikonę napisał ewangelista Łukasz. W każdy wtorek wynoszą ją na teren monasteru - i do dzisiaj czyni ona cuda i [zsyła] uzdrowienie tym, którzy przychodzą [do niej] z wiarą. Pewien mnich wiele modlił się do świętej Bogurodzicy: „Pani, objaw mi się, jaką byłaś w ciele”. I ozwał się do niego głos: „Idź - rzekł - do apostolskiego kościoła, a odnajdziesz mnie napisaną w prezbiterium obok krzyża. Taka byłam ciałem". Był bowiem niegdyś ikonoklazm ${ }^{36}$ w Carogrodzie i zaniesiono ikonę świę-

\footnotetext{
${ }^{36}$ Autor zamieszonego tu tekstu sugeruje, że ikona Bogurodzicy Hodegetrii, pierwotnie znajdująca się w monasterze Hodegon (vide przyp. 29), została przeniesiona do monasteru Chrystusa Pantokratora w okresie ikonoklazmu. Po ostatecznym przywróceniu kultu ikon w Kościele wschodnim przez cesarzową Teodorę w 843 r. miała powrócić na swoje miejsce. Źródła bizantyńskie poświadczają, że monaster Hodegon ucierpiał wskutek działań ikonoklastów, a następnie został odrestaurowany za panowania Michała III (842-867). Odrębną kwestię stanowią natomiast dalsze losy cudownej ikony. Dobrynia Jadrejkowicz (Antoni z Nowogrodu) podziwiał ją ok. 1200 r. w pałacu cesarskim, do którego miała być ona rokrocznie przenoszona w okresie świąt wielkanocnych. George P. Majeska sugeruje, że pojawiająca się w itinerarium diakona Aleksandra i niniejszym tekście opowieść o ukryciu
} 
tej Bogurodzicy Hodegetrii do monasteru Pantokratora ${ }^{37}$, i ukryto ją w ścianie, $\mathrm{w}$ prezbiterium, zapaliwszy przed nią lampkę. I panowali ikonoklaści 60 lat w Carogrodzie, a potem nastała ortodoksja i szukano ikony świętej Bogurodzicy. I nakazał patriarcha modlić się [mnichom] we wszystkich monasterach i pustelnikom. I objawił się [głos] jednemu pustelnikowi w sennym widzeniu: „Szukajcie - rzekł - ikony świętej Bogurodzicy w [monasterze] Pantokratora”. I wnet odnaleziono ją, a lampka nie zgasła w ciągu tych 60 lat, jakby dopiero co została zapalona. I była radość wielka wśród ortodoksów z powodu ikony świętej Bogurodzicy. Tej to ikonie służy ród Łukaszowy i do dzisiaj.

\section{O szacie.}

W Blachernach jest szata świętej Bogurodzicy i kawałek pasa. Przybyły niegdyś wojska nieprzyjacielskie lądem i morzem. Patriarcha Sergiusz umoczył szatę świętej Bogurodzicy w morzu, i wnet zakipiało morze, i utonęli nieprzyjaciele, a inni oślepli i uciekli ze strachu ${ }^{38}$.

artefaktu w monasterze Chrystusa Pantokratora odnosi się nie tyle do epoki sporów o kult ikon, ile - czasu panowania łacinników nad Bosforem. W 1205 r. Wenecjanie wykradli ikonę Bogurodzicy Hodegetrii łacińskiemu patriarsze Konstantynopola, Tomaszowi Morosiniemu i umieścili ją w monasterze Chrystusa Pantokratora, pozostającym wówczas w gestii weneckich duchownych. Miała być tam przechowywana do 1261 roku. W XIV-XV w. znajdowała się zapewne znów w monasterze Hodegon - poświadczają to zgodnie podróżnicy ruscy, m.in. Stefan z Nowogrodu, Ignacy ze Smoleńska, diakon Aleksander i diakon Zosym.

${ }^{37}$ Monaster Chrystusa Pantokratora - ufundowany na początku XII w. przez cesarzową Irenę, żonę Aleksego I Komnena, został udekorowany wieloma mozaikami wyróżniającymi się poziomem artystycznym. W przybytku zgromadzono również kilka cennych relikwii. Najważniejszą z nich była z całą pewnością kamienna płyta, na której Józef z Arymatei i Nikodem mieli złożyć ciało Chrystusa po zdjęciu z krzyża. Została ona przywieziona z Efezu do Konstantynopola przez cesarza Manuela I Komnena. Co ciekawe, Stefan z Nowogrodu, wymieniając relikwie zdeponowane we wspomnianym przybytku (głowy męczenników Flora, Laura i Jakuba Perskiego, zdekapitowane ciało św. Michała oraz naczynie, w którym Chrystus miał przemienić wodę w wino w Kanie Galilejskiej), nie wspomina ani słowem o ikonie Bogurodzicy Hodegetrii. Dodatkowo potwierdza to zatem fakt, iż w jego epoce artefakt ten znajdował się w monasterze Hodegon.

${ }^{38}$ Zostało tu skontaminowanych kilka różnych wydarzeń. Władca perski, Chosroes II Parwiz w porozumieniu z Awarami przypuścił atak na Konstantynopol w 626 roku. Patriarcha konstantynopolitański Sergiusz (610-638) rozkazał wówczas obnosić po murach bizantyńskiej stolicy blacherneńską ikonę Matki Bożej. W okresie późniejszym zrodziła się legenda o osobistej interwencji Bogurodzicy i ocaleniu przez nią cesarskiego miasta. Autor tekstu podaje szczegóły, przynależące do - znanego mu chociażby z kart Powieści minionych lat - opisu ocalenia Konstantynopola przez Marię podczas najazdu Rusów w 860 roku. To wówczas patriarcha Focjusz (858-867, 877-886) miał zanurzyć w wodach morza szatę Bogurodzicy, wywołując burzę, która zniszczyła nieprzyjacielską flotę. Przypisywanie ocalenia Konstantynopola w 626 r. mocy szaty Bogurodzicy, zanurzonej w morzu, jest częstym zjawiskiem w późniejszych tekstach bizantyńskich i ruskich. 


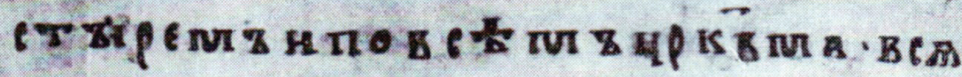

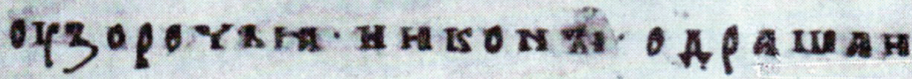

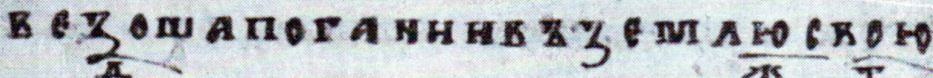

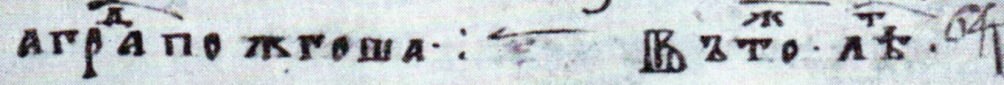

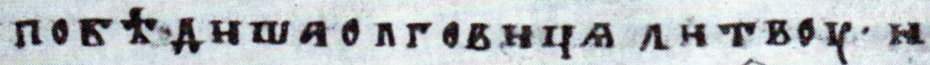

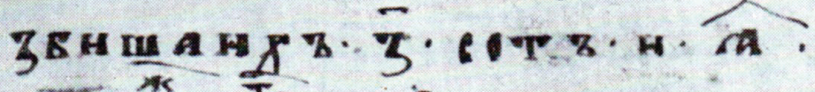

VIV O m 8 -

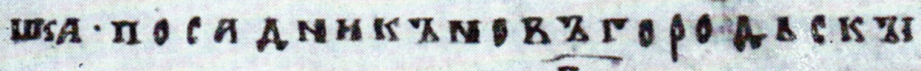
H. กOCTPHER RAOY CTOTE OPFHA-

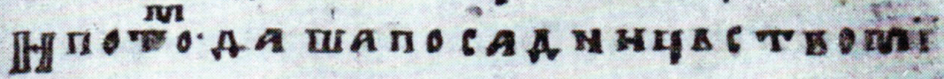
X А

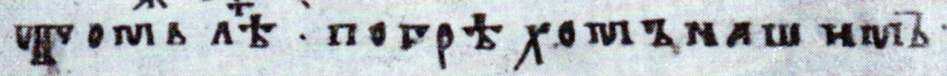
Hzañ $P$ L nock ก०ाम

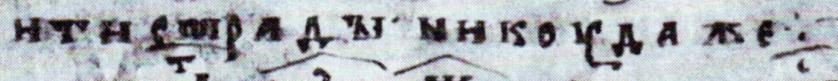

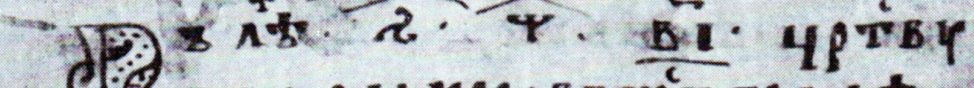
(․ म

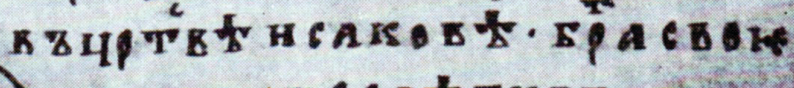

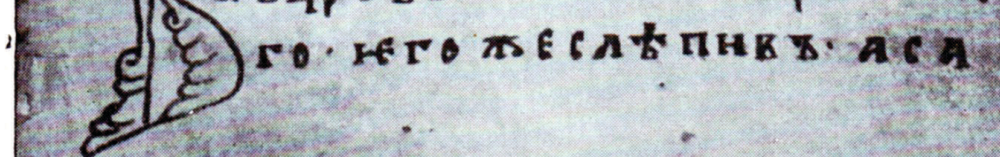




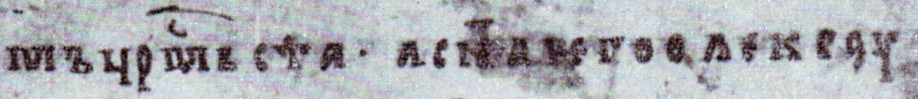

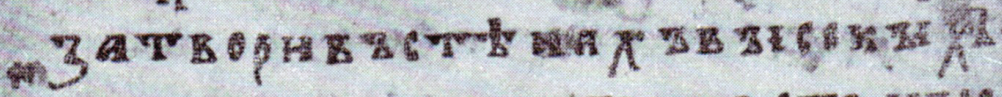

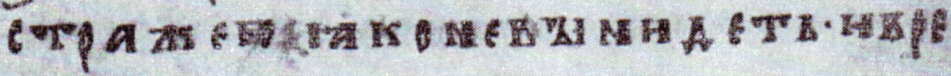
me JुMOY SAIZ

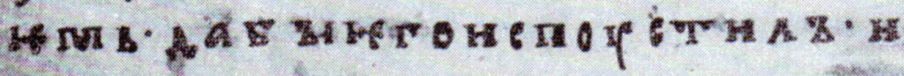

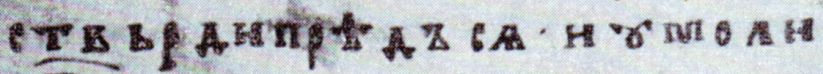

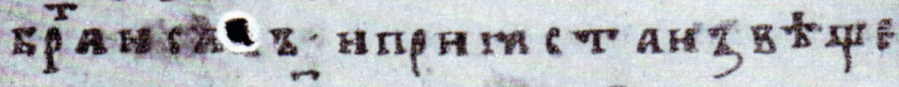
Bด พ

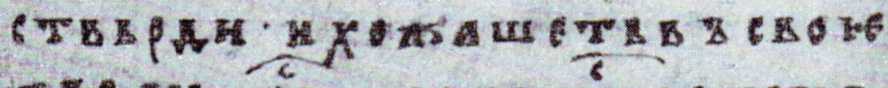

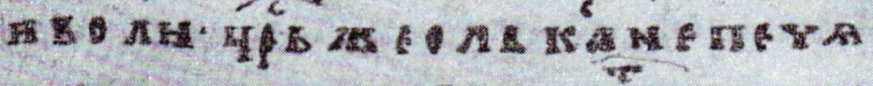
แล C CAQN

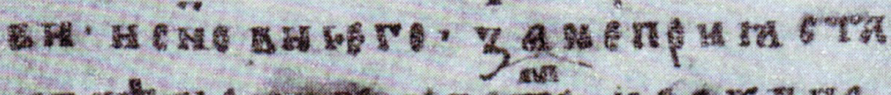

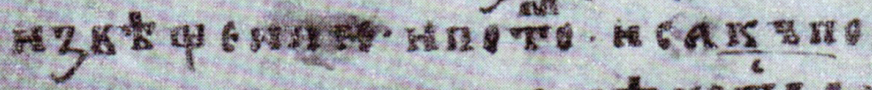

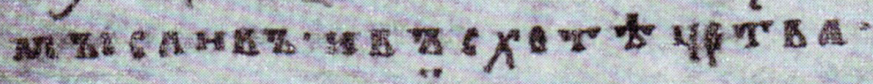

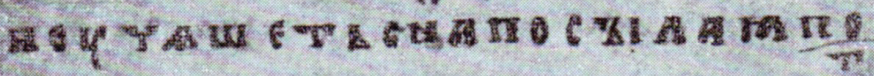
Tra a . स्थ 


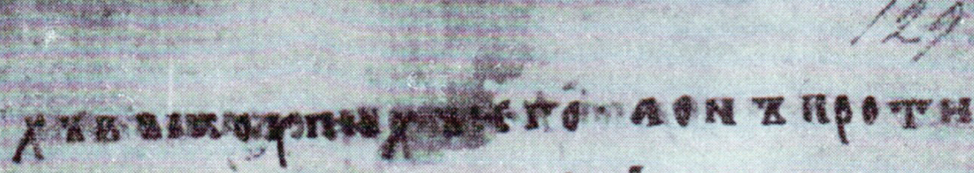

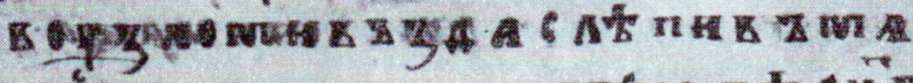

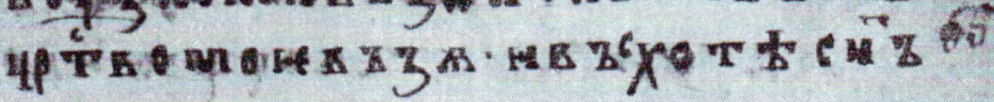

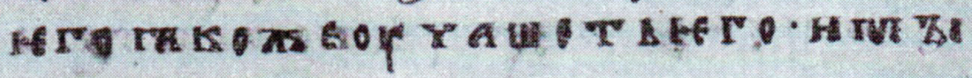

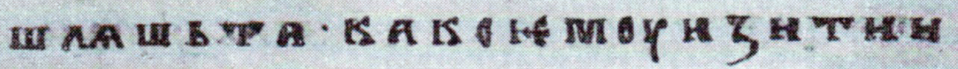
З H

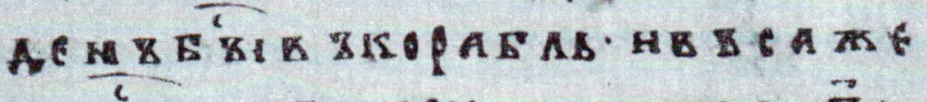
N.

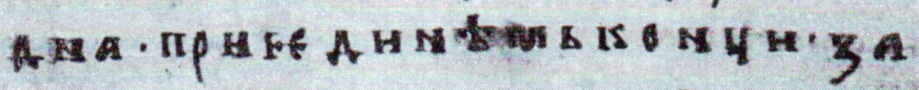

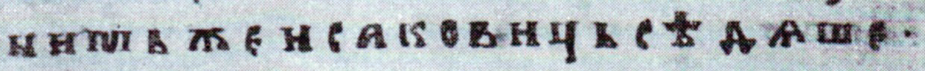

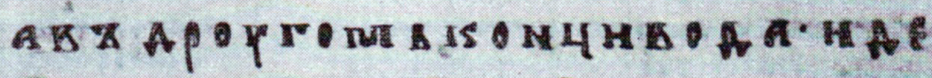

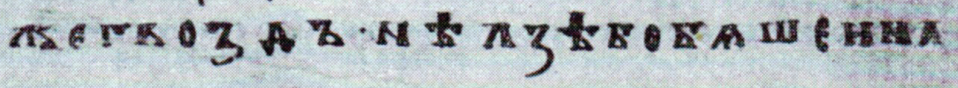

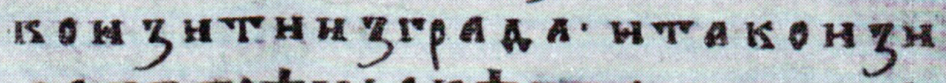

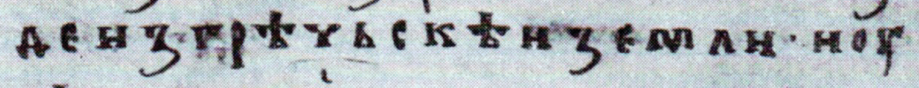
Б

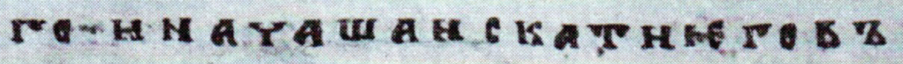

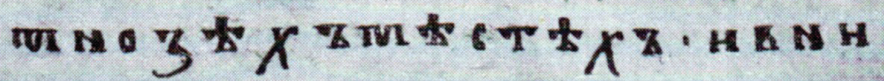

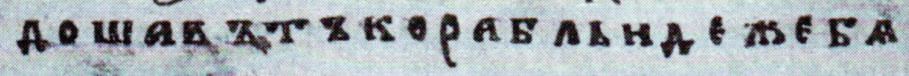


32

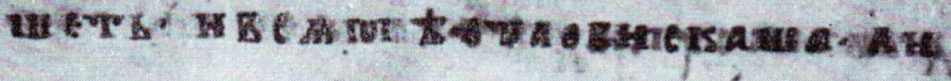
马

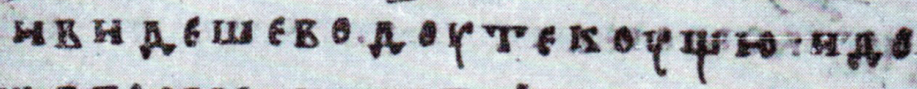
w T"A IS ค.

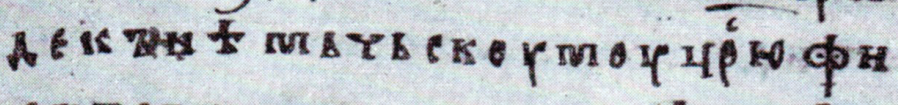

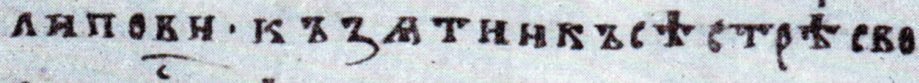

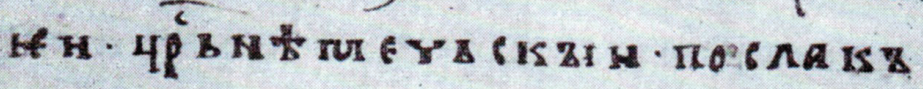
п

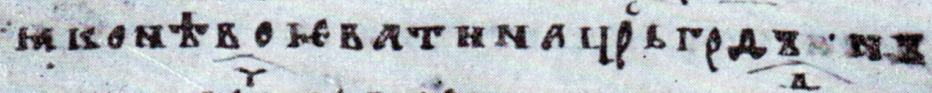

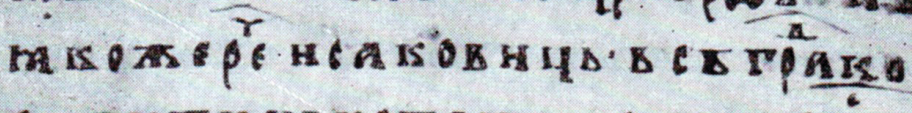

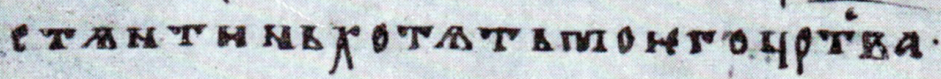

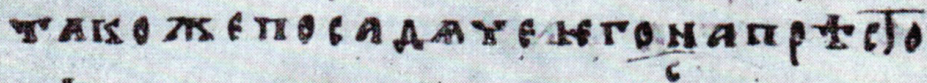
A moñ B 6 A

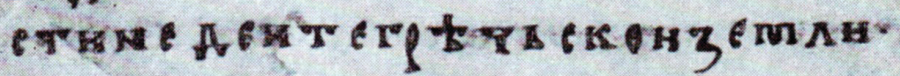

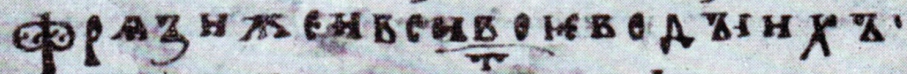

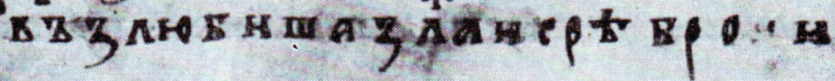




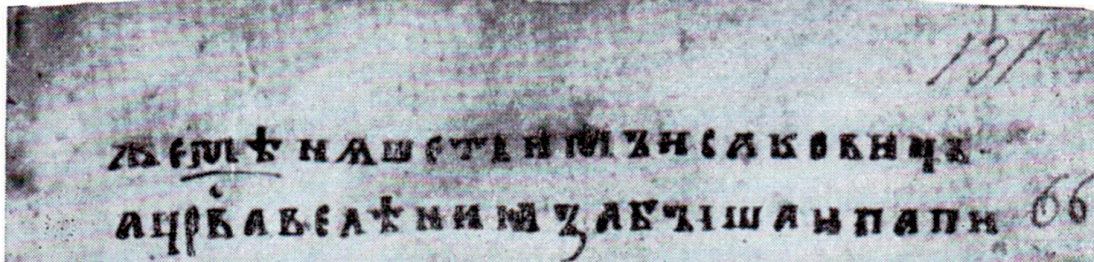

1. ก A. IK H. 2 aru is

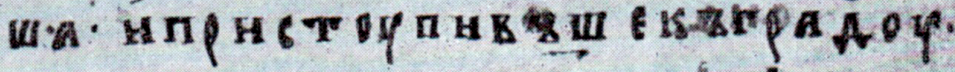
O HAB

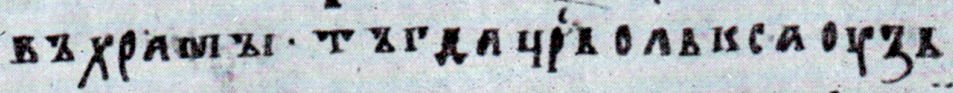

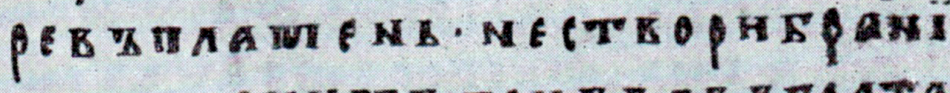

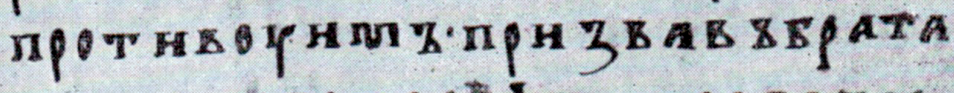

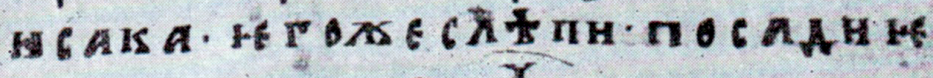

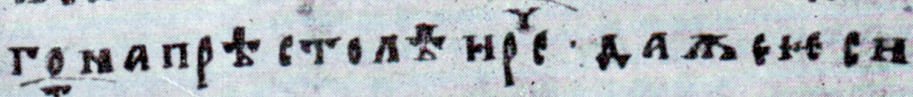
E

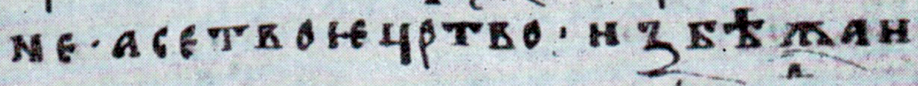

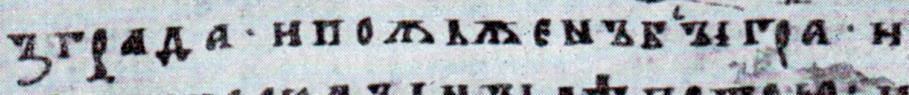

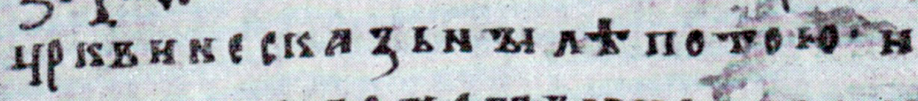

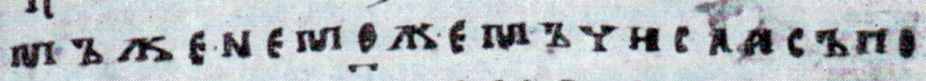

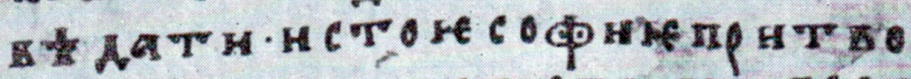
P \& 6 M a 
\%

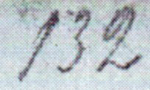

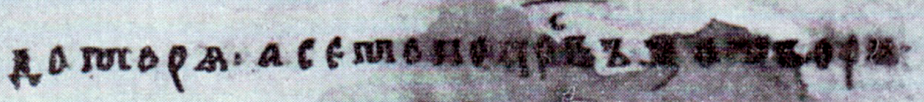

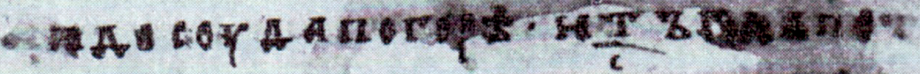

IM H

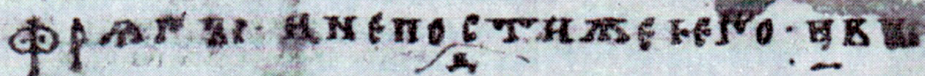

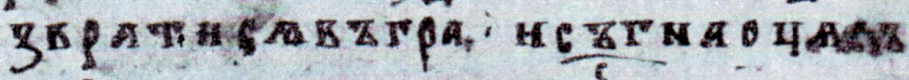
п

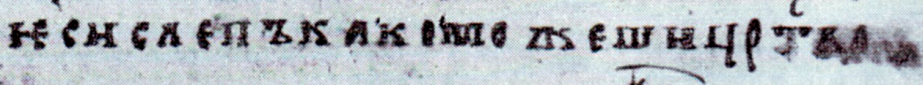

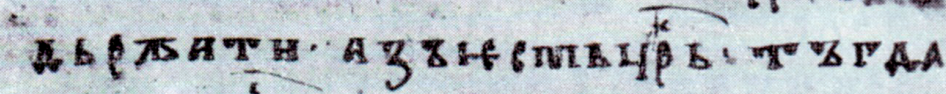

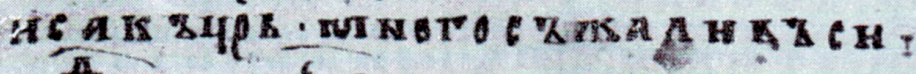

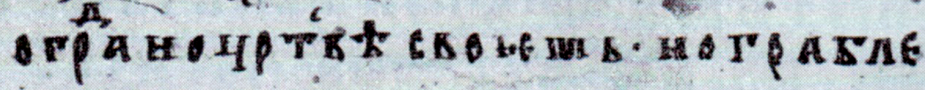

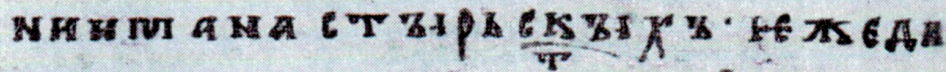
rac CดY К№ 5

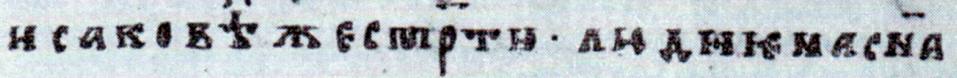

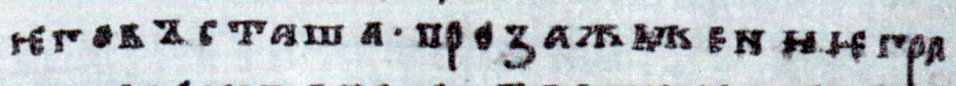

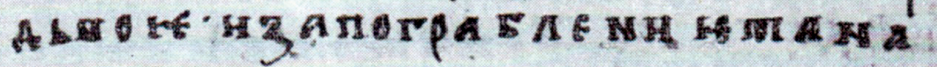
5 गУ B $A$ औ 


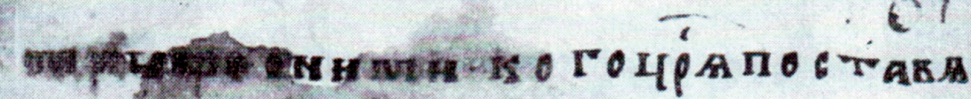

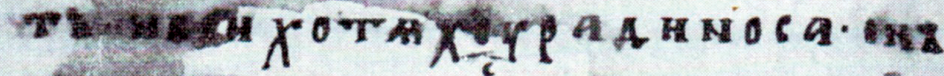

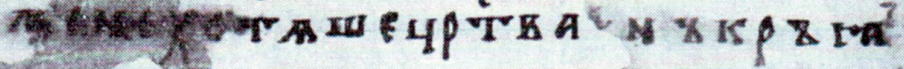
E 6 AW N $X$ X

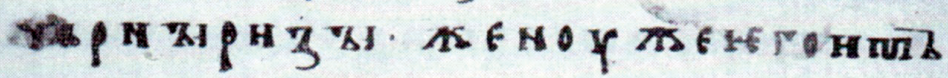
EE IPHEFA.

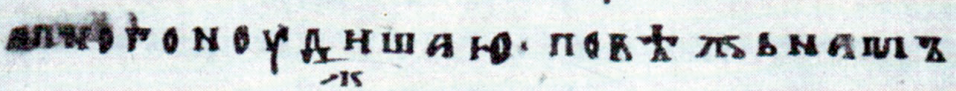

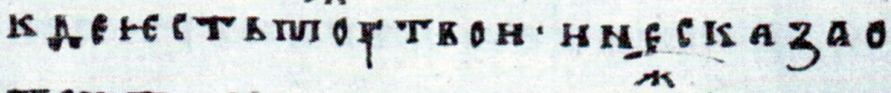

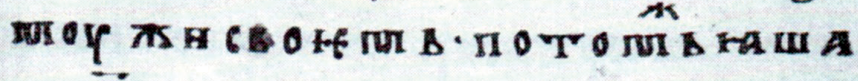

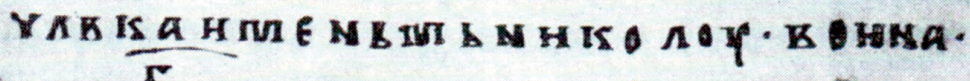

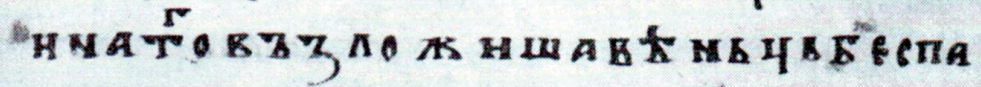
T० 6 TH THK. पṔB TS H Б в п

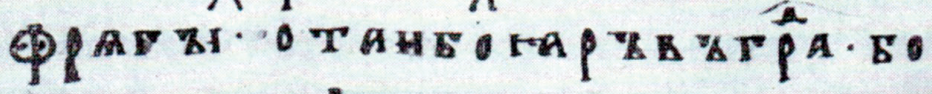
मf

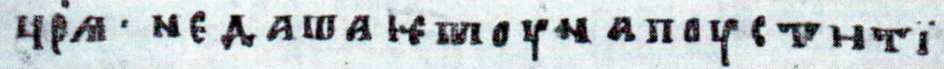
Cด PA T. 
is

\section{4}

-

หน НA

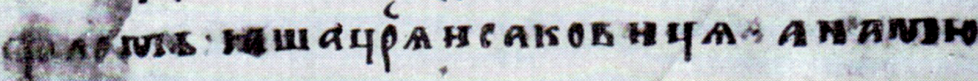

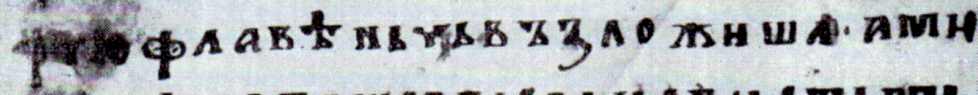

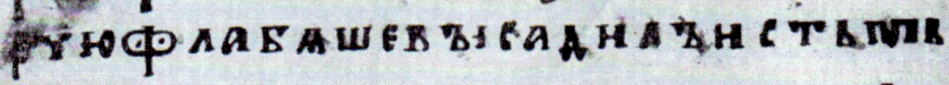

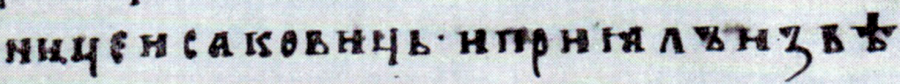

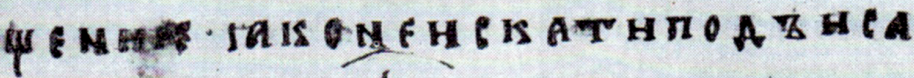

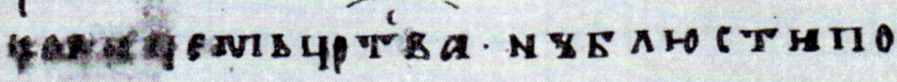
A Thy hotadi IS O cathr rag'

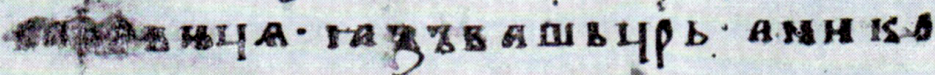
A. A 250 AAW A HE TUO C EOAEZ AI ARU G TБ COHHK КА

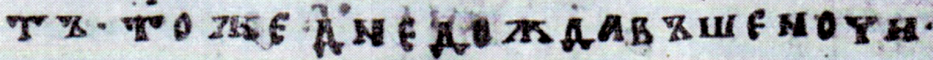

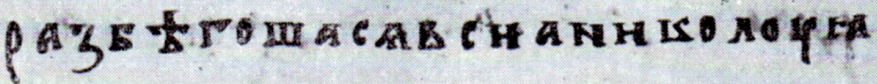




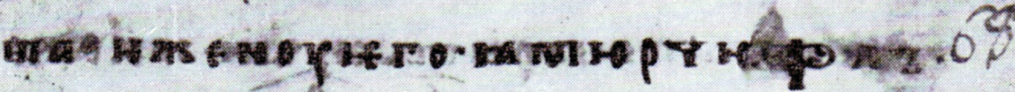
W 5 cois 6

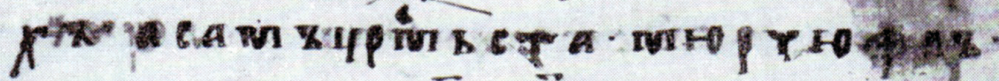

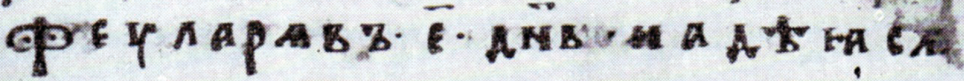
WZ, H W A. aร

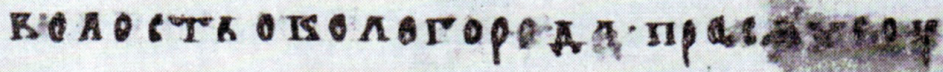
m n

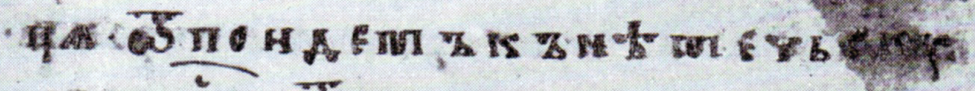

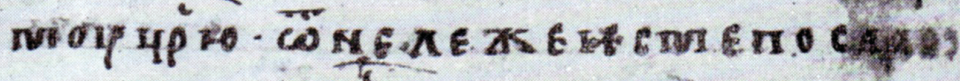

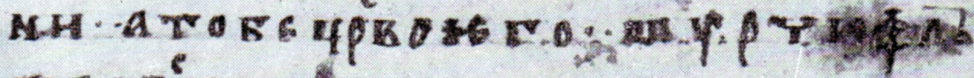
Th $6 \mathrm{~B}$ H

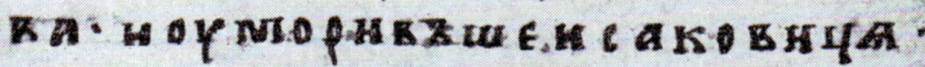

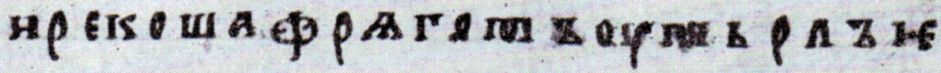

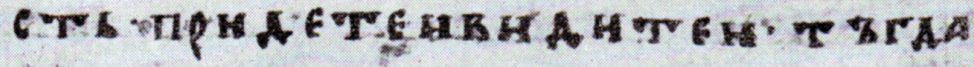

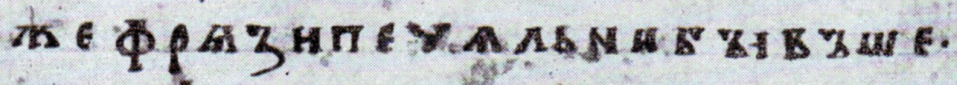

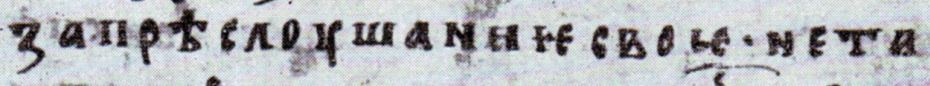

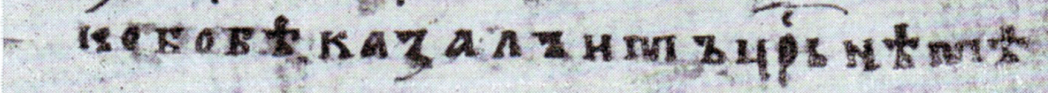




\section{6}

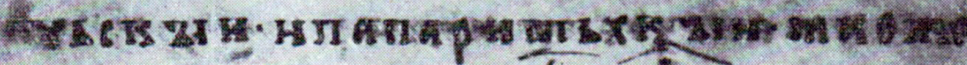

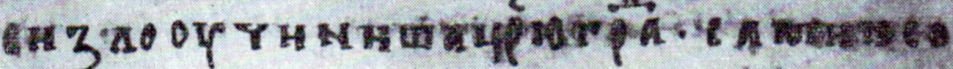

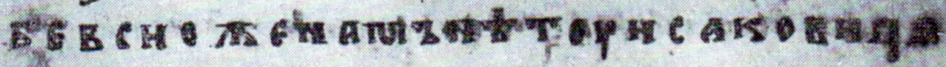

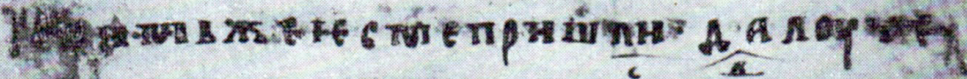

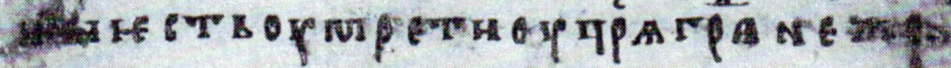

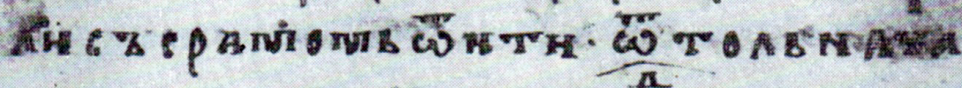

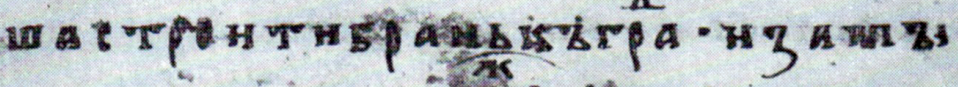

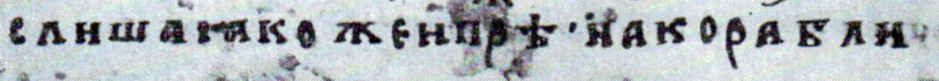

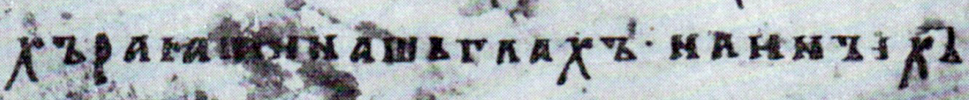

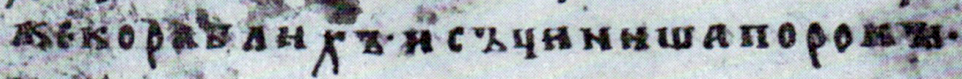

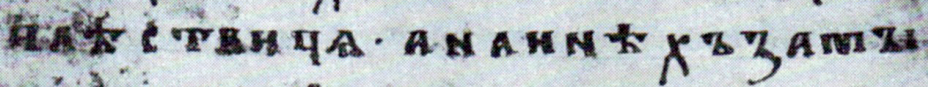

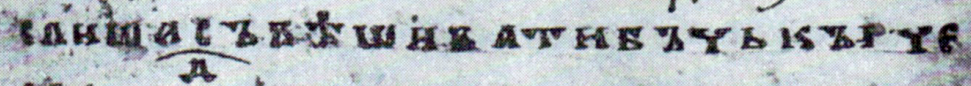

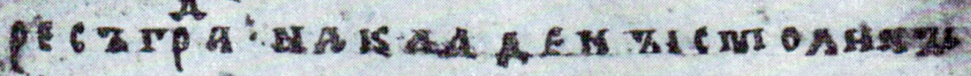

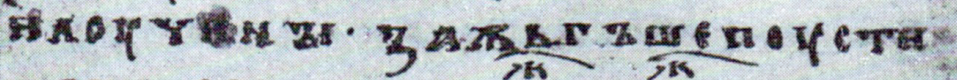
u

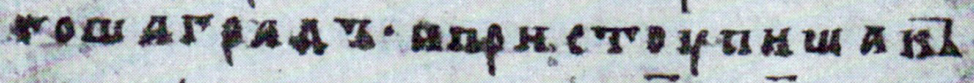
recs a

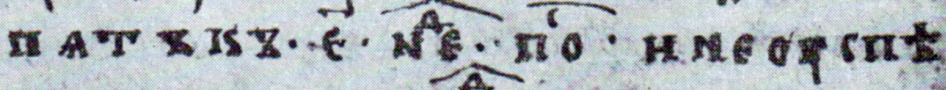
แ 


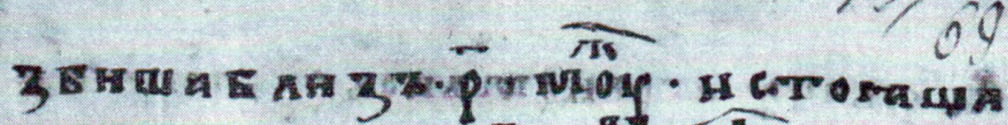
w

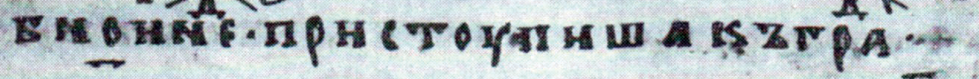
CA 6r 6or. 3 Q

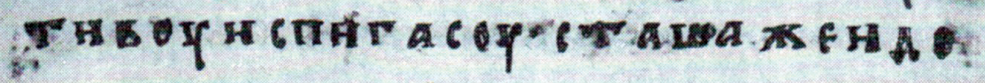
А А $\chi^{\prime}$ Е

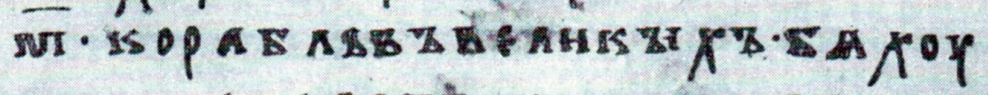

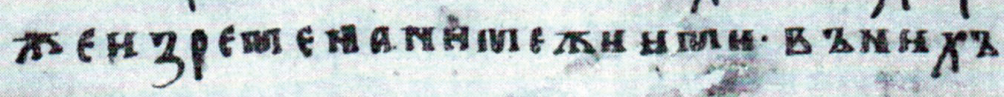

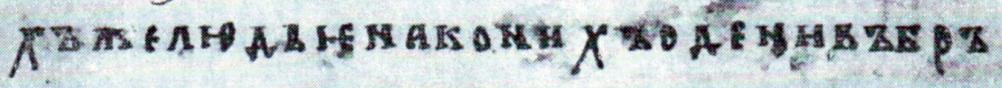

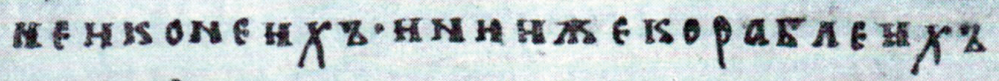

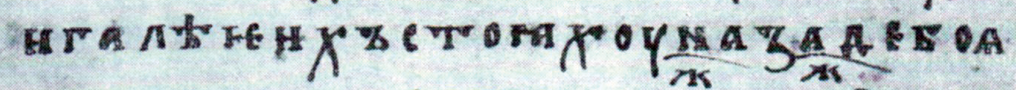
qECA

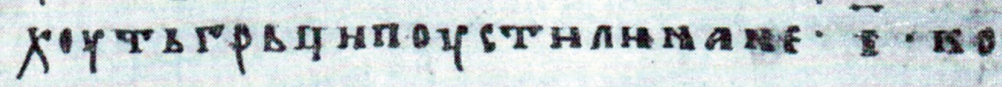

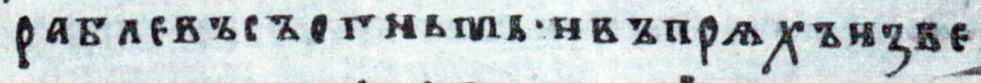

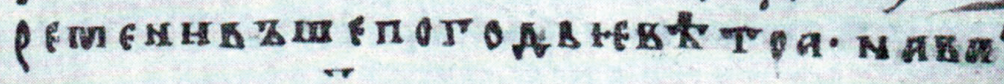

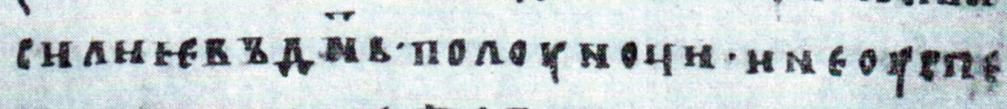

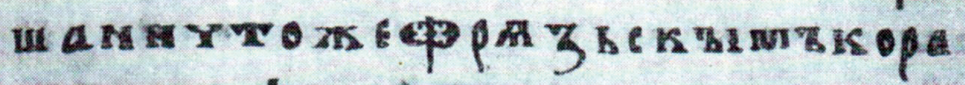
5Af 


\section{8}

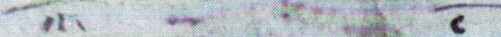

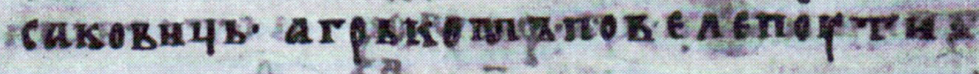

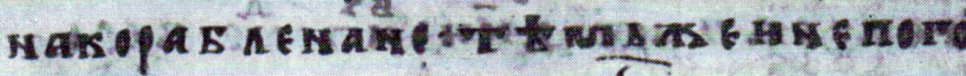

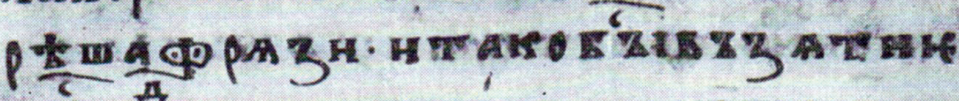

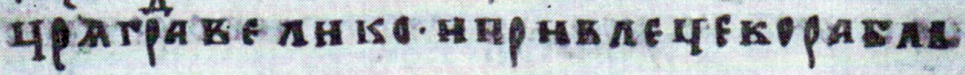

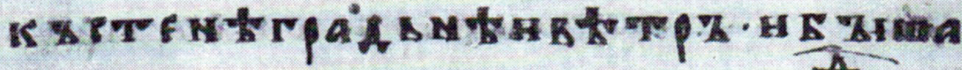

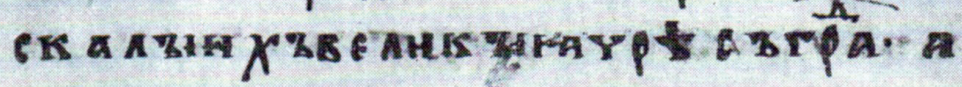

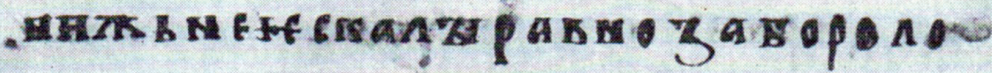

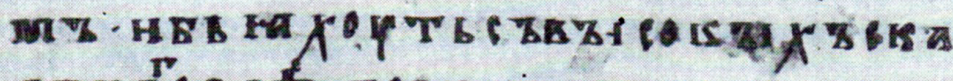
пвкара A

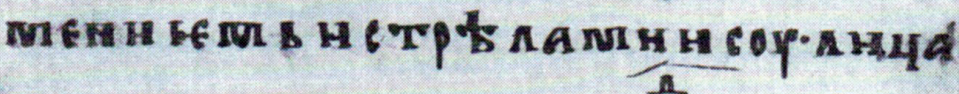

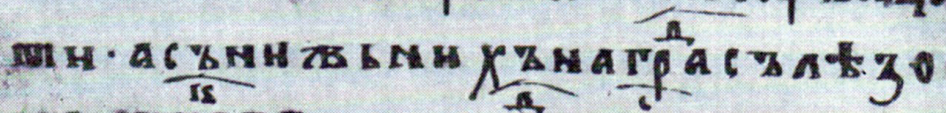

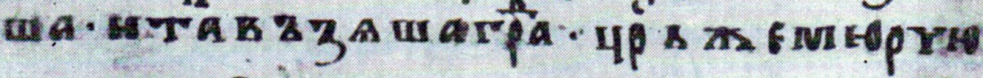

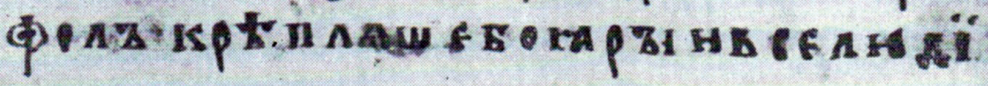
ג"TAт Y एव.भस

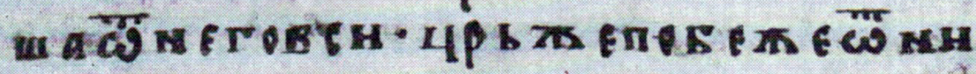
$\chi^{\nabla}$ н OPT"

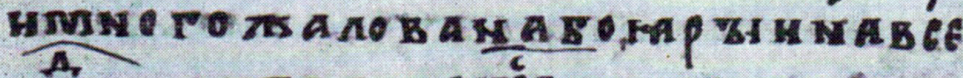
Af० ข 
काँ

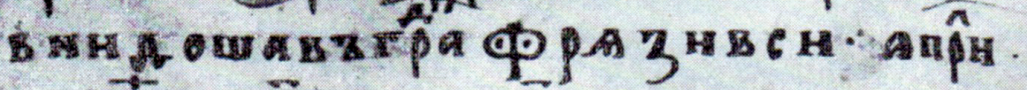

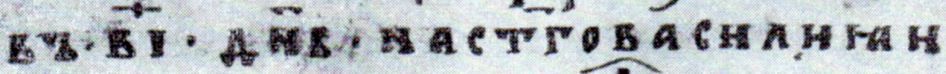

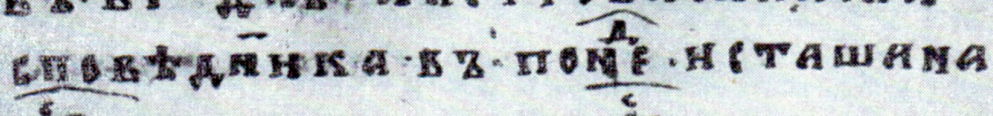

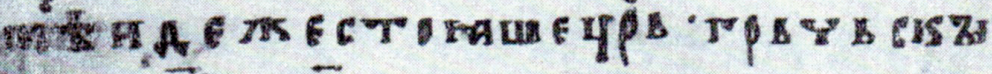

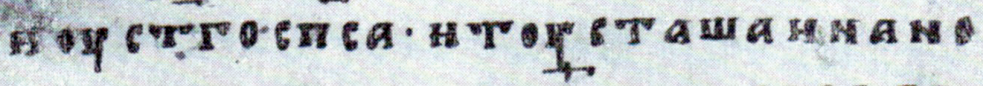

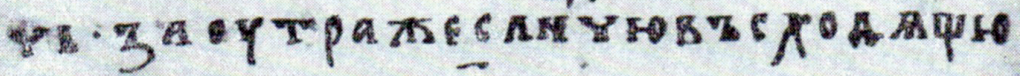

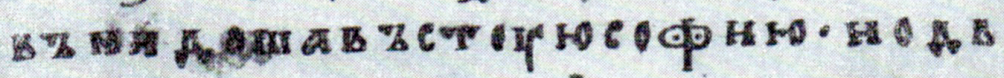

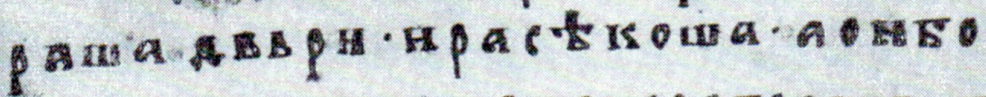

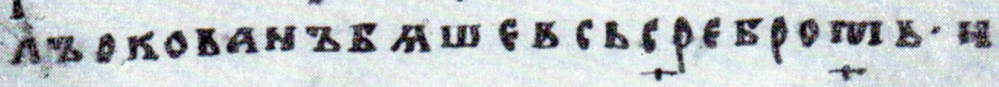

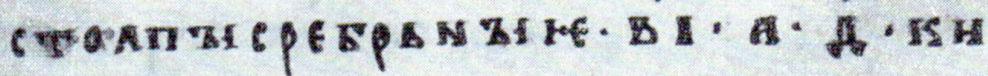

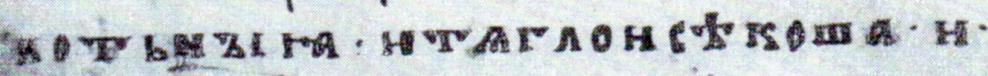
" $X^{4}$ y. В а

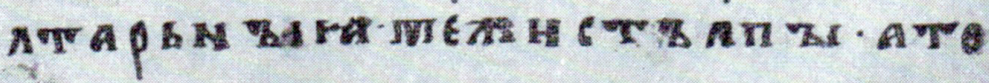

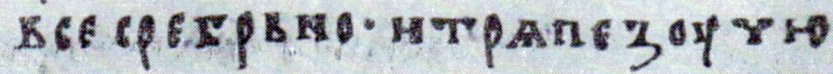

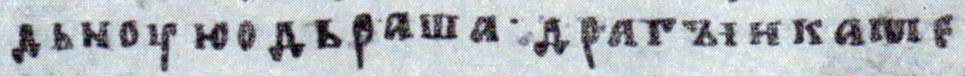

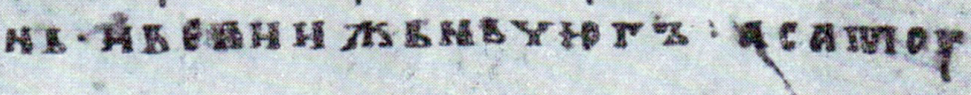




\section{0}

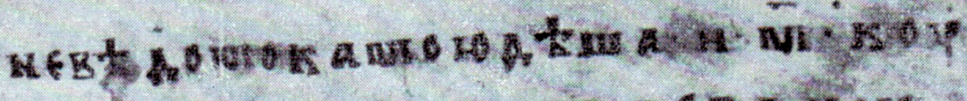

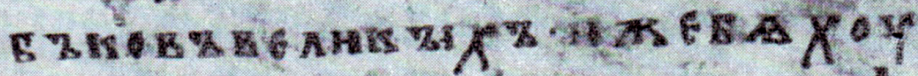

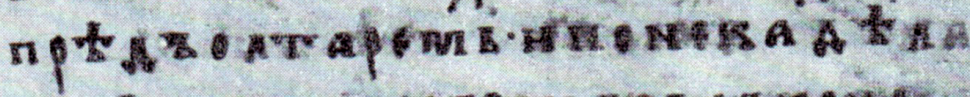
g 5 - 5 กำ उ. 45

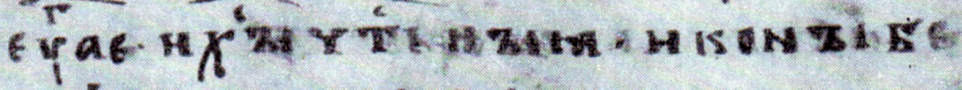

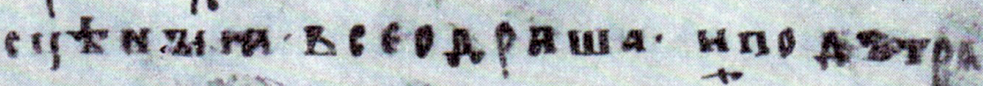

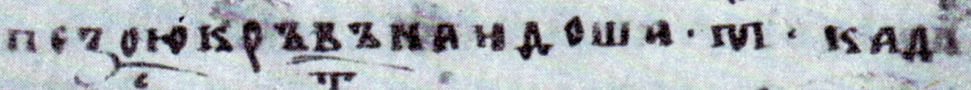

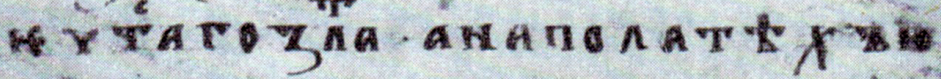

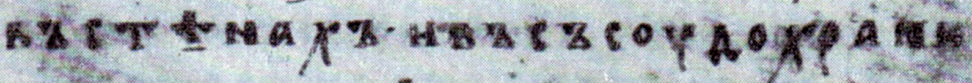
A вp E E $A \cdot$ -

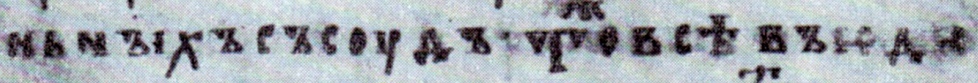
พ จ Eपमी

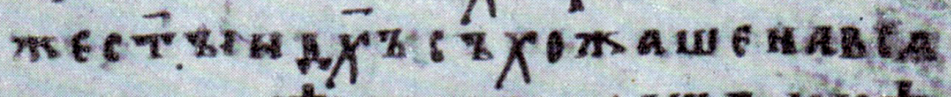

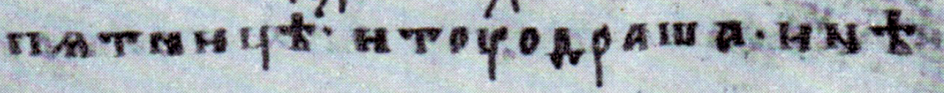


11\%

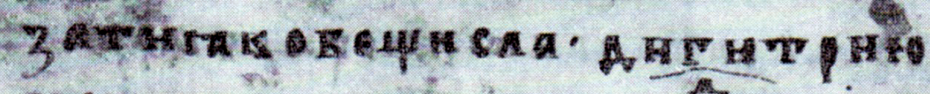

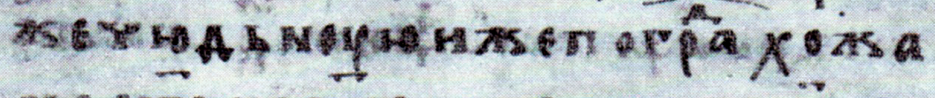

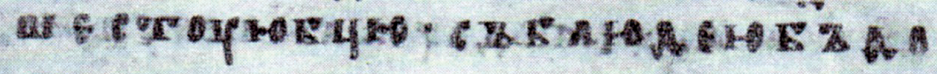
E

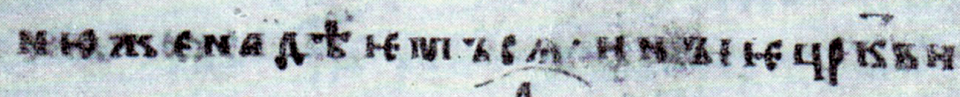
B. 9 W

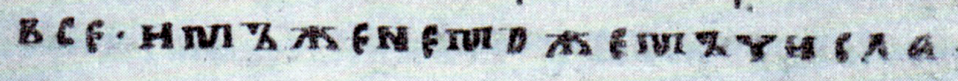

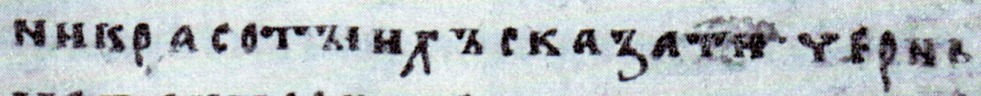

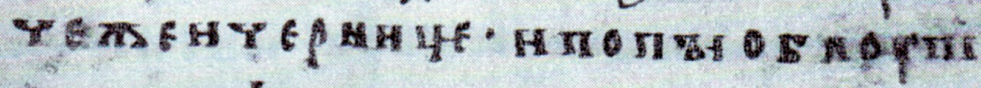

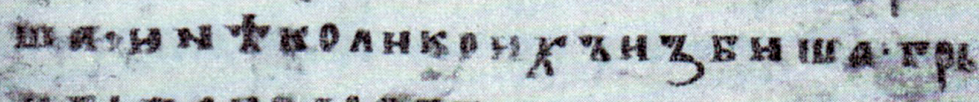
h

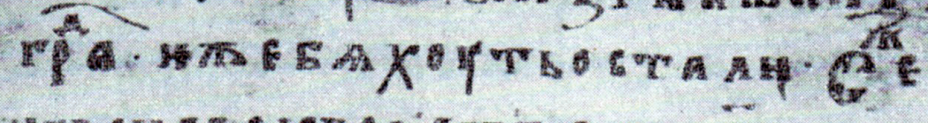

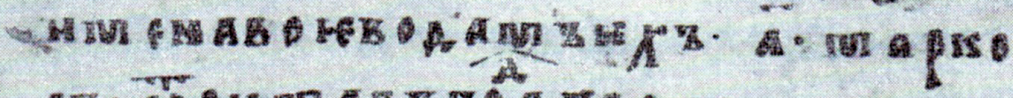

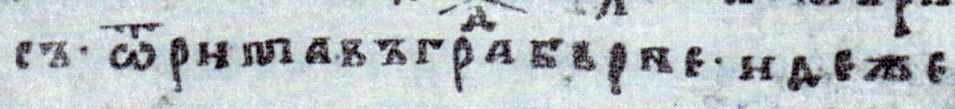

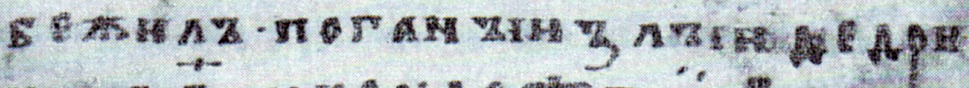

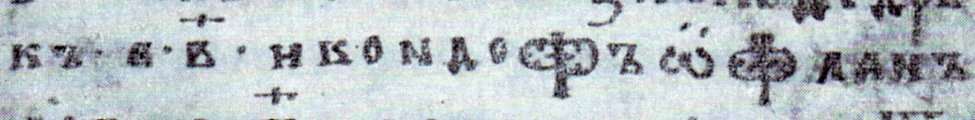
4. 
mags o

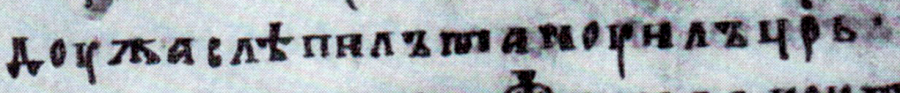

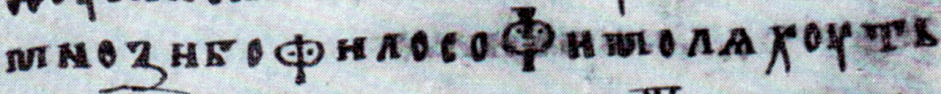

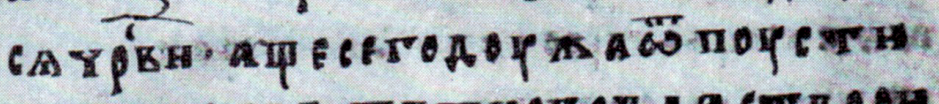
ш

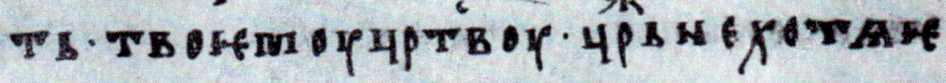

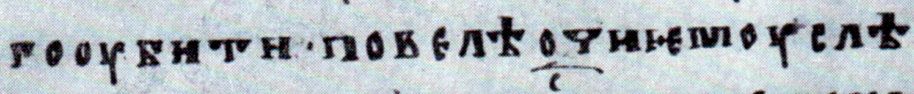

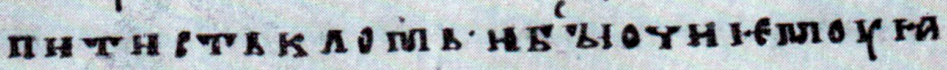
IS MER

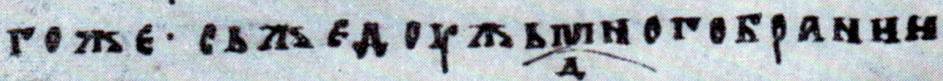
13. 7.

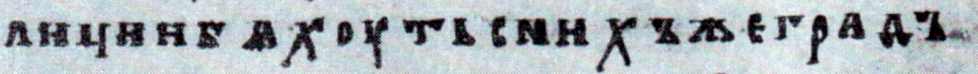

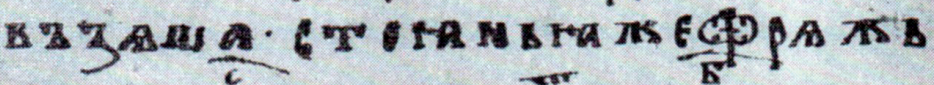

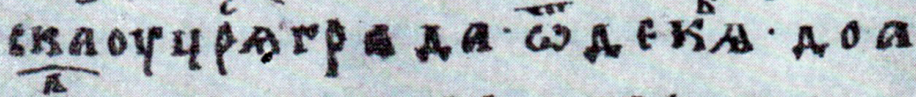

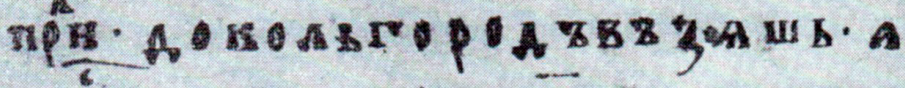

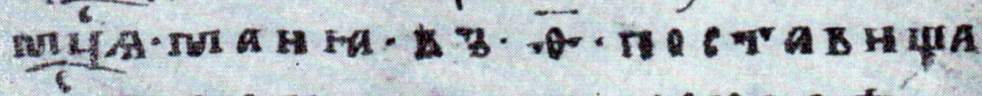

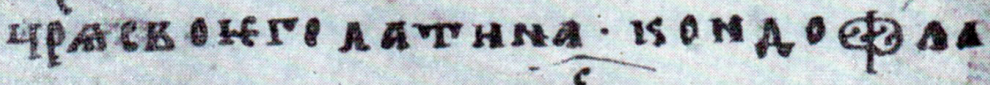

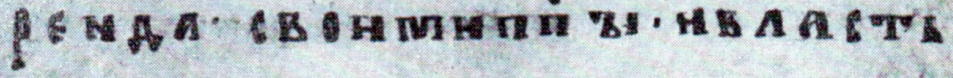


coxep aу PISOcoy? THN

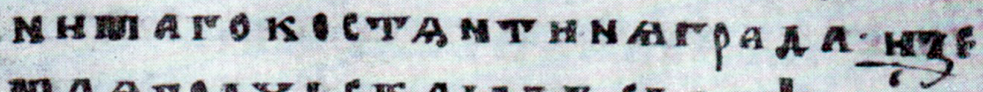

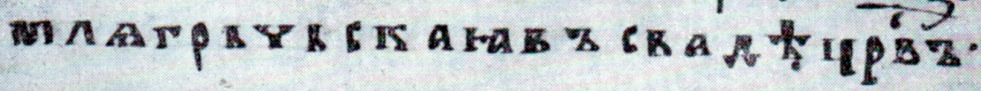
HE FO TS O

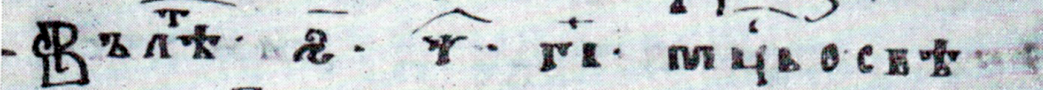

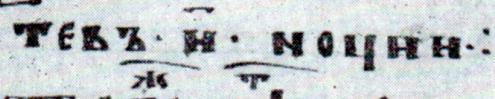

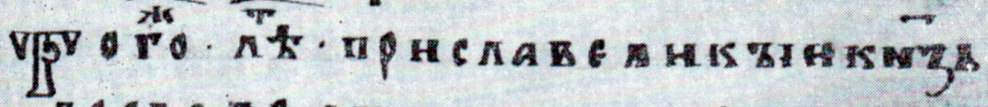

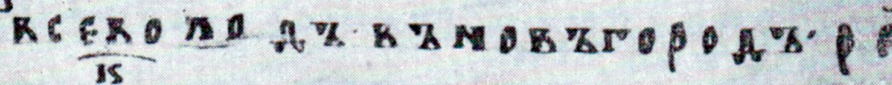

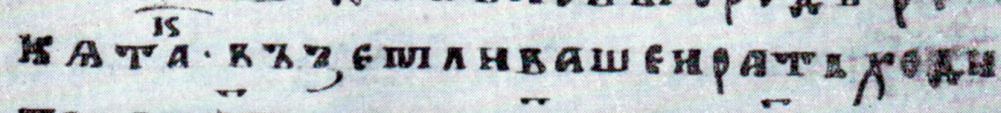
Tू. AIs M ma ละ: WḦ

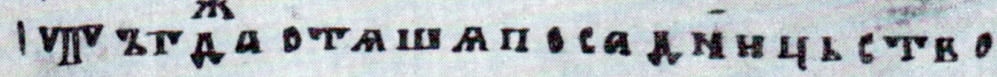
- Y

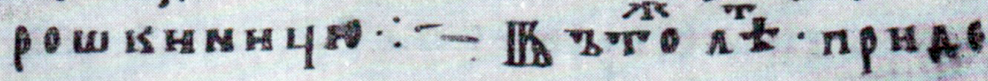

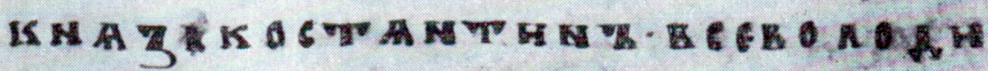
4L. 


\section{LITERATURA}

Geoffroy de Villehardouin 2003, Zdobycie Konstantynopola, thum. Z. Pentek, Poznań, Wydawnictwo Poznańskie.

Nicetas Choniates 1975, Historia, red. J.L. van Dieten, Berolini, Walter de Gruyter.

Robert de Clari 1997, Zdobycie Konstantynopola, thum. Z. Pentek, Poznań, Antykwariat Naukowy im. Jana Konstantego Żupańskiego.

Angold M. 2006, Czwarta krucjata, Warszawa, Wydawnictwo Bellona.

Bednarek B. 2001, Epos europejski, Wrocław, Wydawnictwo Uniwersytetu Wrocławskiego.

Brzozowska Z.A. 2016, Itinerarium Stefana z Nowogrodu z opisem konstantynopolitańskiego portu Kontoskalion (1348/1349). Przektad, w: M.J. Leszka i K. Marinow, red. Miasto na skrzyżowaniu mórz i kontynentów. Wczesno- $i$ Średniobizantyński Konstantynopol jako miasto portowe, Łódź, Wydawnictwo Uniwersytetu Łódzkiego, s. 227-260.

Dąbrowski D. 2012, Daniel Romanowicz. Król Rusi (ok. 1201-1264). Biografia polityczna, Kraków, Wydawnictwo Avalon.

De Mundo S.I. 1950, La Cuarta crazada segun el cronista novgorodense. Anales de historia antigua y medieval, Universidad de Buenos Aires, 2, s. 135-141.

Dollinger P. 1997, Dzieje Hanzy. XII-XVII w., Warszawa, Volumen. Niezależna Oficyna Wydawnicza.

Freydank D. 1968, Die altrussische Erzählung über die Eroberung Konstantinopels 1204 (Chronista Novgorodensis), „Byzantinoslavica”, 29, s. 334-359.

Gordon J. 1973, The Novgorod Account of the Fourth Crusade, „Byzantion”, 43, s. 297-311.

Grala H. 1986, Tradycja dziejopisarska o pobycie władcy Bizancjum w Haliczu (Jan Dlugosz i kronikarz hustyński), „Kwartalnik Historyczny”, 93.3, s. 639-661.

Janin R. 1950, Constantinople byzantine. Développement urbaine et répertoire topographique, Paris, Institut Français d'Études Byzantines.

Kompa A. 2011, Konstantynopolitańskie zabytki w Stambule, Acta Universitatis Lodziensis. Folia Historica, 87 , s. 123-214.

Leszka M.J. i Wolińska T., red. 2011, Konstantynopol - Nowy Rzym. Miasto i ludzie w okresie wczesnobizantyńskim, Warszawa, Wydawnictwo Naukowe PWN.

Madden T.F. 1991/1992, The Fires of the Fourth Crusade in Constantinople 1203-1204. A Damage Assessment, „Byzantinische Zeitschrift”, 84/85, s. 72-93.

Madden T.F. 1993, Venice and Constantinople in 1171 and 1172. Enrico Dandolo's Attitude towards Byzantium, Mediterranean Historical Review, 8.2, s. 166-185.

Madden T.F. 1995, Outside and Inside the Fourth Crusade, The International History Review, 17.4, s. 726-743.

Maiorov A.V. 2016, Eufrozyna Halicka. Córka imperatora bizantyńskiego na Rusi halicko-wołyńskiej (ok. 1176-1180 - po 1253), Kraków, Wydawnictwo Avalon.

Majeska G.P. 1984, Russian Travelers to Constantinople in the $14^{\text {th }}$ and $15^{\text {th }}$ centuries, Washington, Dumbarton Oaks Research Library and Collection.

Meschini M. 2007, 1204. Tajemnica IV wyprawy krzyżowej i podboju Konstantynopola, Kielce, Wydawnictwo „Jedność”.

Nagirnyy V. 2011, Polityka zagraniczna księstw ziem halickiej i wotyńskiej w latach 1198(1199)-1264, Kraków, Polska Akademia Umiejętności.

Naumow A. i Stradomski J. 2005, Echa IV krucjaty w dawnej literaturze ruskiej, w: Z.J. Kijas i M. Salamon, red. IV krucjata. Historia. Reperkusje. Konsekwencje, Kraków, Wydawnictwo WAM, s. $237-251$.

Patri S. 1988, La relation russe de quatrieme croisade, „Byzantion” 58.2, ss. 461-474.

Pentek Z. 2004, Cesarstwo tacińskie 1204-1261. Kolonialne państwo krzyżowców czy Neobizancjum?, Poznań, Wydawnictwo Poznańskie.

- 2005, Z historii IV krucjaty (1198-1204) - zagadnienia polityczne wyprawy i punkty zwrotne w czasie jej trwania, w: Z.J. Kijas i M. Salamon, red. IV krucjata. Historia. Reperkusje. Konsekwencje, Kraków, Wydawnictwo WAM, s. 55-106. 
Quirini-Popławska D. 2005, Znaczenie Republiki Weneckiej we wschodniej części basenu Morza Śródziemnego na przetomie XII/XIII w., w: Z.J. Kijas i M. Salamon, red. IV krucjata. Historia. Reperkusje. Konsekwencje, Kraków, Wydawnictwo WAM, s. 5-30.

Runciman S. 1987, Dzieje wypraw krzyżowych, III, Królestwo Akki i późniejsze krucjaty, Warszawa, Państwowy Instytut Wydawniczy.

Salamon M. 2005, Ocalone świętości. O tradycji ikon, które przetrwały okupację tacińska, w: Z.J. Kijas i M. Salamon, red. IV krucjata. Historia. Reperkusje. Konsekwencje, Kraków, Wydawnictwo WAM, s. $182-193$.

Sawa R. 1991/1992, Opowieść o budowie Wielkiego Kościoła Bożego zwanego kościołem Mądrości Bożej w Konstantynopolu (Narratio de structura templi S. Sophiae), „Vox Patrum”, 11/12.20-23, ss. $409-428$.

Suszko H. 2003, Latopis hustyński. Opracowanie, przeklad i komentarze, Wrocław, Wydawnictwo Uniwersytetu Wrocławskiego.

Van Millingen A. 1899, Byzantine Constantinople. The Walls of the City and Adjoining Historical Sites, London, J. Murray.

Бицилли П.М. 2006, Новгородское сказание о IV-м крестовом походе, w: П.М. Бицилли, Избранные труды по средневековой истории: Россия и Запад, Москва, Языки славянских культур, s. 603-608.

Бобров А.Г. 2001, Новгородские летописи XV в., Санкт-Петербург, Издательство „Дмитрий Буланин".

Бобров А.Г., Клосс Б.М. еd. 2000, Новгородская четвертая летопись, Москва, Языки русской культуры.

Гимон Т.В., Гиппиус А.А. 1999, Новые данные по истории текста Новгородской первой летопиcu, Новгородский исторический сборник, 7(17), s. 18-47.

Гиппиус А.А. 1997, К истории сложения текста Новгородской первой летописи, Новгородский исторический сборник, 6(16), s. 3-72.

Заборов М.А. 1971, Известия русских современников о крестовых походах, Византийский Временник, 31, s. 84-107.

Казакова Н.А. 1975, Русско-ливонские и русско-ганзейскуе отношения. Конеи XIV-начало XVI в., Ленинград, Издательство „Наука”.

Клосс Б.М. 1972, К вопросу о происхождении Еллинского летописиа второго вида, Труды Отдела древнерусской литературы, 27, s. 370-379.

Клосс Б.М., Лурье Я.С. 1976, Русские летописи XI-XV вв. (Материаль для описания), w: Методические рекомендации по описанию славяно-русских рукописей для Сводного каталога рукописей, хранящихся в СССР, II, vol. 2, Москва, Институт истории СССР АН СССР.

Лихачев Д.С. 1948, Еллинский летописеи второго вида и правительственные круги Москвы конца $X V$ в., Труды Отдела древнерусской литературы, 6, s. 100-110.

Лучицкая С.И. 2006, Четвертый крестовый поход глазами русского современника, Византийский Временник, 65, s. 107-125.

Майоров А.В. 2011, Русь, Византия и Западная Европа: Из истории внешнеполитических и культурных связей XII-XIII вв., Санкт-Петербург, Издательство „Дмитрий Буланин”.

Мещерский Н.А. 1954, Древнерусская повесть о взятии Царьграда фрягами в 1204 г., Труды Отдела древнерусской литературы, 10, s. 12-135.

Мещерский Н.А. 1956, Древнерусская повесть о взятии Царьграда фрягами как источник по истории Византии, „Византийский Временник”, 9, s. 170-185.

Подобедова О.И. 1981, Повесть О взятии Царьграда от крестоносиев в 1204 г. в интерпретаиии русского миниатюриста второй половины XVI в., w: Actes du XV Congres International d'etudes byzantines. Athenes, 1976, vol. 2, Art et Archeologie. Communications, Athenes, Association Internationale des Études Byzantines, s. 639-648.

Прончатов Н.Ф. 1967, О значении термина „изременани” в Новгородской летописи, „Византийский Временник”, 27, s. 325-327.

Ракова С. 2007, Четвъртият кръстоносен поход в историческата памет на православните славяни, София, Институт по балканистика. 
Творогов О.В. 1975, Древнерусские хронографы, Ленинград, Издательство „Наука”.

Творогов О.В. 1987, Повесть о взятии Царьграда фрягами, w: Д.С. Лихачев, red., Словарь книжников и книжности Древней Руси (XI - первая половина XIV в.), Ленинград, Издательство „Наука”, s. 352-354.

Творогов О.В. 1989, Летописеи Еллинский и Римский, w: Д.С. Лихачев, red., Словарь книжников и книжности Древней Руси (вторая половина XIV-XVI в.), t. 2, Ленинград, Издательство „Наука", s. 18-20.

Хорошкевич А.Л. 1963, Торговля Великого Новгорода с Прибалтикой и Западной Европой в XIV-XV вв., Москва, Академия наук СССР. 
